\title{
Tropospheric bromine chemistry: implications for present and pre-industrial ozone and mercury
}

\author{
J. P. Parrella ${ }^{1}$, D. J. Jacob ${ }^{1}$, Q. Liang ${ }^{2,3}$, Y. Zhang ${ }^{4}$, L. J. Mickley ${ }^{1}$, B. Miller ${ }^{1}$, M. J. Evans ${ }^{5,6}$, X. Yang ${ }^{7,8}$, J. A. Pyle ${ }^{7,8}$, \\ N. Theys ${ }^{9}$, and M. Van Roozendael ${ }^{9}$ \\ ${ }^{1}$ School of Engineering and Applied Sciences, Harvard University, Cambridge, MA, USA \\ ${ }^{2}$ Universities Space Research Association GESTAR, Columbia, MD, USA \\ ${ }^{3}$ NASA Goddard Space Flight Center, Greenbelt, MD, USA \\ ${ }^{4}$ Department of Atmospheric Sciences, University of Washington, Seattle, Washington, USA \\ ${ }^{5}$ Department of Chemistry, University of York, York, UK \\ ${ }^{6}$ National Centre for Atmospheric Sciences (NCAS), York, UK \\ ${ }^{7}$ National Centre for Atmospheric Sciences (NCAS), Cambridge, UK \\ ${ }^{8}$ Centre for Atmospheric Sciences, Department of Chemistry, University of Cambridge, Cambridge, CB2 1EW, UK \\ ${ }^{9}$ Belgian Institute for Space Aeronomy (IASB-BIRA), Brussels, Belgium
}

Correspondence to: J. P. Parrella (parrella@ fas.harvard.edu)

Received: 5 April 2012 - Published in Atmos. Chem. Phys. Discuss.: 16 April 2012

Revised: 6 July 2012 - Accepted: 9 July 2012 - Published: 1 August 2012

\begin{abstract}
We present a new model for the global tropospheric chemistry of inorganic bromine $\left(\mathrm{Br}_{\mathrm{y}}\right)$ coupled to oxidant-aerosol chemistry in the GEOS-Chem chemical transport model (CTM). Sources of tropospheric $\mathrm{Br}_{\mathrm{y}}$ include debromination of sea-salt aerosol, photolysis and oxidation of short-lived bromocarbons, and transport from the stratosphere. Comparison to a GOME-2 satellite climatology of tropospheric $\mathrm{BrO}$ columns shows that the model can reproduce the observed increase of $\mathrm{BrO}$ with latitude, the northern mid-latitudes maximum in winter, and the Arctic maximum in spring. This successful simulation is contingent on the $\mathrm{HOBr}+\mathrm{HBr}$ reaction taking place in aqueous aerosols and ice clouds. Bromine chemistry in the model decreases tropospheric ozone mixing ratios by $<1-8 \mathrm{nmol} \mathrm{mol}^{-1}(6.5 \%$ globally), with the largest effects in the northern extratropics in spring. The global mean tropospheric $\mathrm{OH}$ concentration decreases by $4 \%$. Inclusion of bromine chemistry improves the ability of global models (GEOS-Chem and p-TOMCAT) to simulate observed 19th-century ozone and its seasonality. Bromine effects on tropospheric ozone are comparable in the present-day and pre-industrial atmospheres so that estimates of anthropogenic radiative forcing are minimally affected. $\mathrm{Br}$ atom concentrations are $40 \%$ higher in the pre-industrial atmosphere due to lower ozone, which would decrease by a
\end{abstract}

factor of 2 the atmospheric lifetime of elemental mercury against oxidation by $\mathrm{Br}$. This suggests that historical anthropogenic mercury emissions may have mostly deposited to northern mid-latitudes, enriching the corresponding surface reservoirs. The persistent rise in background surface ozone at northern mid-latitudes during the past decades could possibly contribute to the observations of elevated mercury in subsurface waters of the North Atlantic.

\section{Introduction}

Bromine radicals $\left(\mathrm{BrO}_{\mathrm{x}} \equiv \mathrm{Br}+\mathrm{BrO}\right)$ are well-known catalysts for ozone destruction in the stratosphere (Clerbaux et al., 2007), and also drive ozone depletion and mercury oxidation in polar surface air (Simpson et al., 2007; Steffen et al., 2008). In the stratosphere, bromine radicals originate from photolysis and oxidation of halons and shorter-lived bromocarbons (Clerbaux et al., 2007; Law et al., 2007). In polar surface air, they originate from photochemistry involving sea salt in aerosol or on sea ice (Simpson et al., 2007; Yang et al., 2008). There is growing evidence that bromine radical chemistry could be important in the background troposphere as well, with remote sensing observations typically 
reporting 0.5-2 $\mathrm{pmol} \mathrm{mol}^{-1} \mathrm{BrO}$ (Harder et al., 1998; Frieß et al., 1999; Fitzenberger et al., 2000; Van Roozendael et al., 2002; Richter et al., 2002; Platt and Hönninger, 2003; Hendrick et al., 2007; Theys et al., 2007, 2011) and aircraft observations reporting several $\mathrm{pmol} \mathrm{mol}^{-1} \mathrm{BrO}$ in the free troposphere (Neuman et al., 2010; Salawitch et al., 2010). Chemical transport model (CTM) studies show that $\sim 1 \mathrm{pmol} \mathrm{mol}^{-1}$ $\mathrm{BrO}$ in the background troposphere would drive significant decrease of ozone (von Glasow et al., 2004; Lary, 2005; Yang et al., 2005) and could account for most of the global oxidation of elemental mercury (Holmes et al., 2006, 2010).

Bromine radical chemistry in the troposphere is initiated by the production of gas-phase inorganic bromine $\left(\mathrm{Br}_{\mathrm{y}}\right)$ from photolysis and oxidation of short-lived bromocarbons and from debromination of sea-salt aerosol (Yang et al., 2005; Kerkweg et al., 2008). $\mathrm{Br}_{\mathrm{y}}$ cycles between $\mathrm{BrO}_{\mathrm{x}}$ and nonradical reservoirs (principally $\mathrm{HBr}, \mathrm{HOBr}, \mathrm{BrNO}_{3}, \mathrm{BrNO}_{2}$, $\mathrm{Br}_{2}$ ) and is eventually lost by deposition. Sea salt aerosol debromination represents the largest source of $\mathrm{Br}_{\mathrm{y}}$ to the troposphere, with estimates between 1000 and $6000 \mathrm{Gg} \mathrm{Bra}^{-1}$ constrained by the observed $\mathrm{Br}$ depletion in sea-salt aerosol relative to seawater composition (Sander et al., 2003). This source is mainly in the marine boundary layer where $\mathrm{Br}_{\mathrm{y}}$ has a short lifetime against deposition. Bromocarbons emitted by the marine biosphere including $\mathrm{CHBr}_{3}, \mathrm{CH}_{2} \mathrm{Br}_{2}$, and $\mathrm{CH}_{3} \mathrm{Br}$ can release $\mathrm{Br}_{\mathrm{y}}$ in the free troposphere where its lifetime against deposition is much longer. Global emission estimates are in the range $370-1400 \mathrm{Gg} \mathrm{Bra}^{-1}$ for $\mathrm{CHBr}_{3}$ and 57-280 Gg Bra ${ }^{-1}$ for $\mathrm{CH}_{2} \mathrm{Br}_{2}$ (Quack and Wallace, 2003; Warwick et al., 2006; Law et al., 2007; Liang et al., 2010; Pyle et al., 2011). $\mathrm{CH}_{3} \mathrm{Br}$ also has a large anthropogenic source as an agricultural pesticide (Clerbaux et al., 2007) and its contribution to tropospheric $\mathrm{Br}_{\mathrm{y}}$ production has been estimated at $60-80 \mathrm{Gg} \mathrm{Br} \mathrm{a}^{-1}$ (Yvon-Lewis et al., 2009). Implementation of these sources in the p-TOMCAT CTM together with relatively well-established gas-phase $\mathrm{Br}_{\mathrm{y}}$ chemistry yields a background tropospheric $\mathrm{BrO}$ mixing ratio of $\sim 0.5 \mathrm{pmol} \mathrm{mol}^{-1}$, at the low end of observations (Yang et al., 2005).

Here we incorporate a detailed simulation capability for tropospheric bromine coupled to oxidant-aerosol chemistry in the GEOS-Chem CTM (Bey et al., 2001). We evaluate this simulation with a recent space-based climatology of tropospheric BrO by Theys et al. (2011). We discuss the effects on tropospheric ozone and mercury budgets for the present-day and pre-industrial atmospheres. Several studies have pointed out the inability of current CTMs to reproduce the low surface ozone observations from the turn of the 20th century, suggesting that CTM-based estimates of the anthropogenic radiative forcing from tropospheric ozone are too low (Wang and Jacob, 1998; Kiehl et al., 1999; Mickley et al., 2001; Shindell et al., 2003; Lamarque et al., 2005; Horowitz, 2006). As we will show, inclusion of bromine chemistry helps to correct this apparent model deficiency.
Table 1. Global sources of tropospheric bromine in GEOS-Chem.

\begin{tabular}{lrr}
\hline Source & $\begin{array}{r}\text { Emission, } \\
\mathrm{Gg} \mathrm{Br} \mathrm{a}^{-1}\end{array}$ & $\begin{array}{r}\text { Lifetime, } \\
\mathrm{d}^{*}\end{array}$ \\
\hline Sea salt debromination & 1420 & $\sim 0$ \\
$\mathrm{CHBr}_{3}$ & 407 & 21 \\
$\mathrm{CH}_{2} \mathrm{Br}_{2}$ & 57 & 91 \\
$\mathrm{CH}_{3} \mathrm{Br}$ & 56 & 402 \\
Transport from stratosphere & 36 & $\sim 0$ \\
\hline
\end{tabular}

* Global mean tropospheric lifetimes of bromocarbons determining the release of $\mathrm{Br}_{\mathrm{y}}$. Values of $\sim 0$ are entered for the sea salt debromination and stratospheric sources because these sources are as $\mathrm{Bry}_{\mathrm{y}}$.

\section{GEOS-Chem bromine simulation}

The GEOS-Chem CTM (http://www.geos-chem.org) has been used extensively for studies of global oxidant-aerosol chemistry. A recent description of the model radical chemistry is given in Mao et al. (2010), and a recent evaluation of the global tropospheric ozone simulation with sonde and satellite observations is given in Zhang et al. (2010). We developed a tropospheric bromine simulation capability fully coupled to the standard oxidant-aerosol chemistry mechanism in version 8-02-02 of the model. The simulation includes ten bromine species transported in the model: $\mathrm{Br}_{2}$, $\mathrm{Br}, \mathrm{BrO}, \mathrm{HBr}, \mathrm{HOBr}, \mathrm{BrNO}_{2}, \mathrm{BrNO}_{3}, \mathrm{CHBr}_{3}, \mathrm{CH}_{2} \mathrm{Br}_{2}$, and $\mathrm{CH}_{3} \mathrm{Br}$. Here we describe the relevant emissions, chemistry, and deposition. All GEOS-Chem simulations presented here have horizontal resolution of $4^{\circ}$ latitude $\times 5^{\circ}$ longitude, 47 vertical layers extending from the surface to $\sim 80 \mathrm{~km}$ in altitude, and an external chemical time step of $1 \mathrm{~h}$. Transport is driven by GEOS-5 assimilated meteorological fields for 2007 from the NASA Global Modeling and Assimilation Office (GMAO). The chemical mechanism is integrated with the SMVGEAR solver for all tropospheric gridboxes (Jacobson and Turco, 1994; Bey et al., 2001). Linear chemistry with climatological rates is used for the stratosphere (Bey et al., 2001), including improved treatment of ozone chemistry with the Linoz parameterization (McLinden et al., 2000). Stratospheric $\mathrm{Br}_{\mathrm{y}}$ concentrations are specified from a model climatology as described below.

\subsection{Tropospheric sources of $\mathrm{Br}_{\mathbf{y}}$}

Tropospheric $\mathrm{Br}_{\mathrm{y}}$ is produced in the model by debromination of sea salt aerosol (SSA), photolysis of $\mathrm{CHBr}_{3}$, and oxidation of $\mathrm{CHBr}_{3}, \mathrm{CH}_{2} \mathrm{Br}_{2}$, and $\mathrm{CH}_{3} \mathrm{Br}$ by $\mathrm{OH}$ (Table 1). SSA observations indicate typically a $50 \%$ loss of bromide $\left(\mathrm{Br}^{-}\right)$ relative to seawater composition, implying release to the atmosphere as $\mathrm{Br}_{\mathrm{y}}$ (Sander et al., 2003). This release may take place by a set of complicated multiphase reactions producing $\mathrm{Br}_{2}, \mathrm{BrCl}$, or $\mathrm{HOBr}$ (Vogt et al., 1996; Sander et al., 1999, 2003), all of which rapidly photolyze to release $\mathrm{BrO}_{\mathrm{x}}$ radicals. Our simplified treatment of SSA debromination follows 
Table 2a. Tropospheric bromine chemistry in GEOS-Chem: bimolecular reactions*.

\begin{tabular}{|c|c|c|c|}
\hline Reaction number & Reaction & $A, \mathrm{~cm}^{3}$ molecule ${ }^{-1} \mathrm{~s}^{-1}$ & $-E_{a} / R, \mathrm{~K}$ \\
\hline R1 & $\mathrm{CHBr}_{3}+\mathrm{OH} \rightarrow 3 \mathrm{Br}+$ products & $1.35 \times 10^{-12}$ & -600 \\
\hline $\mathrm{R} 2$ & $\mathrm{CH}_{2} \mathrm{Br}_{2}+\mathrm{OH} \rightarrow 2 \mathrm{Br}+$ products & $2.00 \times 10^{-12}$ & -840 \\
\hline R3 & $\mathrm{CH}_{3} \mathrm{Br}+\mathrm{OH} \rightarrow \mathrm{Br}+$ products & $2.35 \times 10^{-12}$ & -1300 \\
\hline R4 & $\mathrm{Br}+\mathrm{O}_{3} \rightarrow \mathrm{BrO}+\mathrm{O}_{2}$ & $1.60 \times 10^{-11}$ & -780 \\
\hline R5 & $\mathrm{Br}+\mathrm{CH}_{2} \mathrm{OHBr}+\mathrm{HO}_{2}+\mathrm{CO}$ & $1.70 \times 10^{-11}$ & -800 \\
\hline R6 & $\mathrm{Br}+\mathrm{HO}_{2} \rightarrow \mathrm{HBr}+\mathrm{O}_{2}$ & $4.80 \times 10^{-12}$ & -310 \\
\hline R7 & $\mathrm{Br}+\mathrm{CH}_{3} \mathrm{CHO} \mathrm{HBr}+\mathrm{CH}_{3} \mathrm{CO}_{3}$ & $1.30 \times 10^{-11}$ & -360 \\
\hline $\mathrm{R} 8$ & $\mathrm{Br}+\left(\mathrm{CH}_{3}\right)_{2} \mathrm{CO} \mathrm{HBr}+\mathrm{CH}_{3} \mathrm{C}(\mathrm{O}) \mathrm{CH}_{2} \mathrm{OO}$ & $1.66 \times 10^{-10}$ & -7000 \\
\hline R9 & $\mathrm{Br}+\mathrm{C}_{2} \mathrm{H}_{6} \mathrm{HBr}+\mathrm{C}_{2} \mathrm{H}_{5} \mathrm{OO}$ & $2.36 \times 10^{-10}$ & -6411 \\
\hline R10 & $\mathrm{Br}+\mathrm{C}_{3} \mathrm{H}_{8} \mathrm{HBr}+\mathrm{C}_{3} \mathrm{H}_{7} \mathrm{OO}$ & $8.77 \times 10^{-10}$ & -4330 \\
\hline R11 & $\mathrm{Br}+\mathrm{BrNO}_{3} \rightarrow \mathrm{Br}_{2}+\mathrm{NO}_{3}$ & $4.90 \times 10^{-11}$ & 0 \\
\hline R12 & $\mathrm{Br}+\mathrm{NO}_{3} \rightarrow \mathrm{BrO}+\mathrm{NO}_{2}$ & $1.60 \times 10^{-11}$ & 0 \\
\hline R13 & $\mathrm{HBr}+\mathrm{OH} \rightarrow \mathrm{Br}+\mathrm{H}_{2} \mathrm{O}$ & $5.50 \times 10^{-12}$ & 200 \\
\hline R14 & $\mathrm{BrO}+\mathrm{NO} \rightarrow \mathrm{Br}+\mathrm{NO}_{2}$ & $8.80 \times 10^{-12}$ & 260 \\
\hline R15 & $\mathrm{BrO}+\mathrm{OH} \rightarrow \mathrm{Br}+\mathrm{HO}_{2}$ & $1.70 \times 10^{-11}$ & 250 \\
\hline R16 & $\mathrm{BrO}+\mathrm{BrO} \rightarrow 2 \mathrm{Br}+\mathrm{O}_{2}$ & $2.40 \times 10^{-12}$ & 40 \\
\hline R17 & $\mathrm{BrO}+\mathrm{BrO} \rightarrow \mathrm{Br}_{2}+\mathrm{O}_{2}$ & $2.80 \times 10^{-14}$ & 860 \\
\hline R18 & $\mathrm{BrO}+\mathrm{HO}_{2} \rightarrow \mathrm{HOBr}+\mathrm{O}_{2}$ & $4.50 \times 10^{-12}$ & 460 \\
\hline R19 & $\mathrm{Br}_{2}+\mathrm{OH} \rightarrow \mathrm{HOBr}+\mathrm{Br}$ & $2.10 \times 10^{-11}$ & 240 \\
\hline
\end{tabular}

* The Arrhenius expression for rate constants is $k=A \exp \left(-E_{a} / R T\right)$. Kinetic data are from Sander et al. (2011) except for Reactions (R7) (Atkinson et al., 2000), (R8) (King et al., 1970), (R9) and (R10) (Seakins et al., 1992), and (R11) (Orlando and Tyndall, 1996).

the Yang et al. (2005) observation-based parameterization of $\mathrm{Br}^{-}$depletion factors relative to seawater for particles in the 1-10 $\mu \mathrm{m}$ diameter range. These depletion factors are applied to the size-dependent SSA source function in GEOS-Chem (Alexander et al., 2005). Uncertainties in modeled debromination are introduced by the parameterization of bromide depletion (Sander et al., 2003) as well as the factor of 4 uncertainty in sea salt aerosol sources (Lewis and Schwartz, 2004). The resulting $\mathrm{Br}_{\mathrm{y}}$ is released as $\mathrm{Br}_{2}$ uniformly through the depth of the marine boundary layer (MBL) diagnosed from the GEOS-5 meteorological data. Though SSA debromination is the largest source of tropospheric $\mathrm{Br}_{\mathrm{y}}$ in GEOS-Chem, removal by deposition in the MBL is fast. We find that this source contributes $48 \%$ of $\mathrm{Br}_{\mathrm{y}}$ in the global free troposphere, the rest originating from bromocarbons.

$\mathrm{CHBr}_{3}$ and $\mathrm{CH}_{2} \mathrm{Br}_{2}$ are emitted from oceanic macroalgae and phytoplankton (Quack and Wallace, 2003; Yokouchi et al., 2005; Butler et al., 2007), and are thought to be the dominant bromocarbon precursors for tropospheric $\mathrm{Br}_{\mathrm{y}}$ (Warwick et al., 2006; Law et al., 2007). We use emission estimates from Liang et al. (2010) for different latitudinal bands and including enhancements in coastal regions (Carpenter et al., 1999), based on ship cruise data (Quack and Wallace, 2003; Warwick et al., 2006) and refined with airborne observations (Liang et al., 2010). The Liang et al. (2010) emission estimates are aseasonal, but we add seasonality to the $\mathrm{CHBr}_{3}$ source in the northern extratropics $\left(>30^{\circ} \mathrm{N}\right)$ as described below to better match observations. Both $\mathrm{CHBr}_{3}$ and $\mathrm{CH}_{2} \mathrm{Br}_{2}$ in the model are removed by oxidation by $\mathrm{OH}$, and $\mathrm{CHBr}_{3}$ is in addition removed by photolysis (Table 2). We compute mean tropospheric lifetimes for $\mathrm{CHBr}_{3}$ and $\mathrm{CH}_{2} \mathrm{Br}_{2}$ of 21 days and 91 days respectively (Table 1 ). Photochemical loss of $\mathrm{CHBr}_{3}$ and $\mathrm{CH}_{2} \mathrm{Br}_{2}$ is assumed to release all available $\mathrm{Br}$ instantaneously in our model. This approximation was shown to be reasonable in a modeling study by Hossaini et al. (2010).

We evaluated our simulations of $\mathrm{CHBr}_{3}$ and $\mathrm{CH}_{2} \mathrm{Br}_{2}$ with observations from NASA aircraft campaigns previously used by Liang et al. (2010) in the evaluation of their GEOS Climate Chemistry Model (GEOS CCM) simulation. We sampled GEOS-Chem results as averages for the coherent spatial domains of each campaign and for the appropriate months, following the standard methodology used for model evaluation of other species (Bey et al., 2001; Fischer et al., 2012). The observations are for years other than our 2007 simulation year but we regard interannual variability as only a small source of error.

Figure 1 shows composite vertical profiles of $\mathrm{CHBr}_{3}$ and $\mathrm{CH}_{2} \mathrm{Br}_{2}$ mixing ratios for the tropics and northern extratropics in April-June. The shapes of the vertical profiles test the model vertical transport modulated by atmospheric lifetime, including in particular the delivery to the free troposphere where the lifetime of $\mathrm{Br}_{\mathrm{y}}$ against deposition is long. We see from Fig. 1 that observed vertical gradients are steeper for $\mathrm{CHBr}_{3}$ than for $\mathrm{CH}_{2} \mathrm{Br}_{2}$, and steeper in the extratropics 
Table 2b. Tropospheric bromine chemistry in GEOS-Chem: three-body reactions ${ }^{\mathrm{a}}$.

\begin{tabular}{lll}
\hline Reaction number & Reaction & Rate coefficients ${ }^{\mathrm{b}}$ \\
\hline $\mathrm{R} 20$ & $\mathrm{Br}+\mathrm{NO}_{2}+\mathrm{M} \rightarrow \mathrm{BrNO}_{2}+\mathrm{M}$ & $k_{0}=4.2 \times 10^{-31}(T / 300)^{-2.4} ; k_{\infty}=2.7 \times 10^{-11}, F_{c}=0.6$ \\
\hline $\mathrm{R} 21$ & $\mathrm{BrO}+\mathrm{NO}_{2}+\mathrm{M} \rightarrow \mathrm{BrNO}_{3}+\mathrm{M}$ & $k_{0}=5.2 \times 10^{-31}(T / 300)^{-3.2} ; k_{\infty}=6.9 \times 10^{-12}, F_{c}=0.6$ \\
\hline $\begin{array}{l}\text { a } \\
\text { The rate constant is calculated as } k=\left\{\left[k_{0}[\mathrm{M}] /\left(1+k_{0}[\mathrm{M}] / k_{\infty}\right)\right] \times F_{c}^{n}\right\}, \text { where } n=\left\{1+\left(\log _{10}\left(k_{0}[\mathrm{M}] / k_{\infty}\right)\right)^{2}\right\}^{-1} \text { and }[\mathrm{M}] \text { is the air number density }\end{array}$ \\
$\begin{array}{l}\left.\text { bolecules } \mathrm{cm}^{-3}\right) . \\
\text { from Sander et al. }(2011) ; k_{0} \text { and } k_{\infty} \text { have units of } \mathrm{cm}^{6} \text { molecule }^{-2} \mathrm{~s}^{-1} \text { and } \mathrm{cm}^{3} \text { molecule }{ }^{-1} \mathrm{~s}^{-1} \text { respectively, and } T \text { has unit of } \mathrm{K} .\end{array}$
\end{tabular}

Table 2c. Tropospheric bromine chemistry in GEOS-Chem: threebody reactions ${ }^{\mathrm{a}}$.

\begin{tabular}{lll}
\hline $\begin{array}{l}\text { Reaction } \\
\text { number }\end{array}$ & Reaction & $J, \mathrm{~s}^{-1 \mathrm{~b}}$ \\
\hline $\mathrm{R} 22$ & $\mathrm{CHBr}_{3}+h v \rightarrow 3 \mathrm{Br}+$ products & $1.1 \times 10^{-6}$ \\
$\mathrm{R} 23$ & $\mathrm{Br}_{2}+h v \rightarrow 2 \mathrm{Br}$ & $4.2 \times 10^{-2}$ \\
$\mathrm{R} 24$ & $\mathrm{BrO}+h v \stackrel{\mathrm{O}_{2}}{\longrightarrow} \mathrm{Br}+\mathrm{O}_{3}$ & $4.0 \times 10^{-2}$ \\
$\mathrm{R} 25$ & $\mathrm{HOBr}+h v \rightarrow \mathrm{Br}+\mathrm{OH}$ & $2.3 \times 10^{-3}$ \\
$\mathrm{R} 26$ & $\mathrm{BrNO}_{2}+h v \rightarrow \mathrm{Br}+\mathrm{NO}_{2}$ & $1.2 \times 10^{-3}$ \\
$\mathrm{R} 27$ & $\mathrm{BrNO}_{3}+h v \rightarrow \mathrm{BrO}+\mathrm{NO}_{2}$ & $2.2 \times 10^{-4}$ \\
$\mathrm{R} 28$ & $\mathrm{BrNO}_{3}+h v \rightarrow \mathrm{Br}+\mathrm{NO}_{3}$ & $1.2 \times 10^{-3}$ \\
\hline
\end{tabular}

a photolysis rates are calculated locally with the Fast-J radiative transfer model (Wild et al., 2000) using absorption cross-sections from Sander et al. (2011) except for Reaction (R26) (Scheffler et al., 1997). All quantum yields are assumed to be $100 \%$ (Sander et al., 2011).

${ }^{b}$ global annual tropospheric mean photolysis frequencies calculated in GEOS-Chem.

than in the tropics, reflecting the differences in lifetimes. The model reproduces well these observations.

Figure 2 compares seasonal tropospheric columns of $\mathrm{CHBr}_{3}$ and $\mathrm{CH}_{2} \mathrm{Br}_{2}$ in the tropics and northern extratropics for the ensemble of NASA aircraft campaigns. This provides a test of emissions in the model. We find that the aseasonal emissions of $\mathrm{CHBr}_{3}$ from Liang et al. (2010) overestimate $\mathrm{CHBr}_{3}$ columns in the northern extratropics during winter and spring, and therefore we apply a seasonal correction factor to these emissions as shown in the figure. No systematic bias is otherwise apparent for $\mathrm{CHBr}_{3}$ in the tropics or for $\mathrm{CH}_{2} \mathrm{Br}_{2}$. Our global $\mathrm{CHBr}_{3}$ source is $407 \mathrm{Gg} \mathrm{Bra}^{-1}$ globally (compared to $425 \mathrm{Gg} \mathrm{Br} \mathrm{a}^{-1}$ in Liang et al., 2010). Pyle et al. (2011) recently estimated a global $\mathrm{CHBr}_{3}$ source of $380 \mathrm{Gg} \mathrm{Bra}^{-1}$ constrained with observations from the OP3 campaign over the maritime continent. Our global $\mathrm{CH}_{2} \mathrm{Br}_{2}$ source is $57 \mathrm{Gg} \mathrm{Bra}^{-1}$, same as Liang et al. (2010).

$\mathrm{CH}_{3} \mathrm{Br}$ has a sufficiently long lifetime to be wellmixed in the troposphere. Surface air observations from the NOAA/GMD global network show a near-uniform mixing ratio of 6-9 $\mathrm{pmol} \mathrm{mol}^{-1}$ (Montzka et al., 2003) and we use these as lower boundary condition in the model: $6.7 \mathrm{pmol} \mathrm{mol}^{-1}$ in the Southern Hemisphere and $8.5 \mathrm{pmol} \mathrm{mol}^{-1}$ in the Northern Hemisphere. The implied

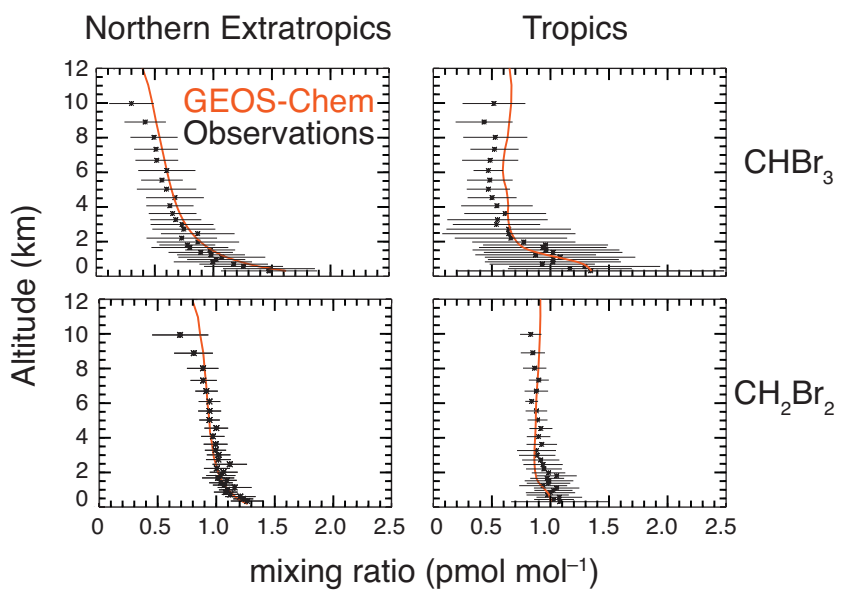

Fig. 1. Mean vertical profiles of $\mathrm{CHBr}_{3}$ and $\mathrm{CH}_{2} \mathrm{Br}_{2}$ concentrations in the northern extratropics (latitudes $>30^{\circ} \mathrm{N}$ ) and tropics $\left(30^{\circ} \mathrm{S}-30^{\circ} \mathrm{N}\right)$ for April-June. GEOS-Chem model results (in red) are compared to observations from NASA aircraft campaigns (in black) including TRACE-P, INTEX-B, and ARCTAS. See Liang et al. (2010) for references on the aircraft observations. Vertical profiles have been averaged over coherent regions for individual missions and then averaged again over the latitudinal domain. Horizontal bars are standard deviations in the original data.

tropospheric source of $\mathrm{Br}_{\mathrm{y}}$ to balance the computed $\mathrm{CH}_{3} \mathrm{Br}$ sink in GEOS-Chem is $56 \mathrm{Gg} \mathrm{Bra}^{-1}$, slightly lower than a previous estimate of $63-78 \mathrm{Gg} \mathrm{Bra}^{-1}$ (Saltzman et al., 2004).

Halons and other bromocarbons photolyzed or oxidized in the stratosphere represent an additional source of $\mathrm{Br}_{\mathrm{y}}$ to the troposphere. This is treated here as an upper boundary condition above the local model tropopause using archived $\mathrm{Br}_{\mathrm{y}}$ concentrations from the Liang et al. (2010) stratospheric simulation with the GEOS-5 CCM. The mean stratospheric $\mathrm{Br}_{\mathrm{y}}$ mixing ratio in that simulation is $22 \mathrm{pmol} \mathrm{mol}^{-1}$. We use monthly mean 3-D concentration data from Liang et al. (2010) for individual $\mathrm{Br}_{\mathrm{y}}$ species, separately for daytime and nighttime. The resulting cross-tropopause source of tropospheric $\mathrm{Br}_{\mathrm{y}}$ in GEOS-Chem is $36 \mathrm{Gg} \mathrm{Bra}^{-1}$, as determined by difference with a sensitivity simulation using a zero-concentration upper boundary condition for all $\mathrm{Br}_{\mathrm{y}}$ species above the tropopause. 
Table 2d. Tropospheric bromine chemistry in GEOS-Chem: heterogeneous processes.

\begin{tabular}{lll}
\hline Reaction number & Reaction & Reactive uptake probability $(\gamma)^{\mathrm{a}}$ \\
\hline R29 & $\mathrm{BrNO}_{3} \stackrel{\mathrm{H}_{2} \mathrm{O} \text { (aerosol, cloud) }}{\longrightarrow} \mathrm{HOBr}+\mathrm{HNO}_{3}$ & 0.3 (sea salt, liquid cloud) $^{\mathrm{b}}, 0.8$ (sulfate) $^{\mathrm{c}}$ \\
$\mathrm{R} 30$ & $\mathrm{HOBr}+\mathrm{HBr} \stackrel{\text { aqueous aerosol, ice }}{\longrightarrow} \mathrm{Br}_{2}+\mathrm{H}_{2} \mathrm{O}$ & 0.2 (sea salt, sulfate), 0.1 (ice) $^{\mathrm{c}}$ \\
\hline
\end{tabular}

${ }^{\text {a }}$ See Eq. (1) in text; ${ }^{\mathrm{b}}$ IUPAC evaluation (Atkinson et al., 2000b); ${ }^{\mathrm{c}}$ Sander et al. (2011); for Reaction (R30) the reactive uptake probability is applied to the limiting reactant.

Table 2e. Tropospheric bromine chemistry in GEOS-Chem: Henry's law constants ${ }^{\mathrm{a}}$.

\begin{tabular}{llll}
\hline Species & $K_{\mathrm{H}}(298), \mathrm{M} \mathrm{atm}^{-1}$ & $-\Delta H / R, \mathrm{~K}$ & Reference \\
\hline $\mathrm{HBr}$ & $0.75\left(7.5 \times 10^{13}\right)^{\mathrm{b}}$ & 10200 & Schweitzer et al. (2000) \\
$\mathrm{HOBr}$ & $6100^{\mathrm{c}}$ & $6010^{\mathrm{d}}$ & Frenzel et al. (1998) \\
$\mathrm{Br}$ & 0.76 & 4180 & Dean (1992) \\
$\mathrm{Br}$ & 1.2 & 1800 & Sander (1999) \\
$\mathrm{BrO}^{\mathrm{e}}$ & 0.71 & & Frenzel et al. (1998) \\
$\mathrm{BrNO}_{2}$ & 0.3 & & Frenzel et al. (1998) \\
$\mathrm{BrNO}_{3}^{\mathrm{g}}$ & $\infty$ & & Sander (1999)
\end{tabular}

a The Henry's law constant is calculated as

$K_{\mathrm{H}}(T)=K_{\mathrm{H}}(298) \exp \left[\frac{-\Delta H}{R}\left(\frac{1}{T}-\frac{1}{298}\right)\right]$, where $K_{\mathrm{H}}(298)$ is the value at $298 \mathrm{~K}$,

$\Delta H$ is the enthalpy of solution, $R$ is the gas constant, and $T$ is the temperature (K)

b The Henry's Law constant is from Schweitzer et al. (2000); The value in parentheses is the effective Henry's law constant $K_{\mathrm{H}}^{*}$ at $\mathrm{pH} 5$ accounting for

$\mathrm{HBr}_{(\mathrm{aq})} / \mathrm{Br}^{-}$acid dissociation: $K_{\mathrm{H}}^{*}(T)=K_{\mathrm{H}}(T)\left(1+\frac{K_{a}}{\left[\mathrm{H}^{+}\right]}\right)$, where

$K_{\mathrm{a}}=1 \times 10^{9} \mathrm{M}$ is the acid dissociation constant (Arnaud, 1966).

${ }^{\mathrm{c}} \mathrm{HOBr}(\mathrm{aq}) / \mathrm{BrO}^{-}$acid dissociation is negligible under atmospheric conditions

$\left(K_{\mathrm{a}}=1.6 \times 10^{-9} \mathrm{M}\right.$, Haag and Hoigne, 1983).

${ }^{\mathrm{d}}$ McGrath and Rowland (1994)

e $\mathrm{Br}_{2}$ (aq) dissociation by hydrolysis can be neglected (Beckwith et al., 1996).

${ }^{\mathrm{f}}$ Estimated by analogy with $\mathrm{ClO}$ (Sander et al., 2011).

$\mathrm{g} \mathrm{BrNO}_{3}$ uptake by liquid clouds is modeled by a reactive uptake probability

(Table 2d) and is not limited by Henry's law solubility. For modeling dry deposition

an infinite Henry's law constant is assumed.

Other tropospheric $\mathrm{Br}_{\mathrm{y}}$ sources are neglected as unimportant on a global scale. Kerkweg et al. (2008) estimated that photo-oxidation of bromocarbons other than $\mathrm{CHBr}_{3}$, $\mathrm{CH}_{2} \mathrm{Br}_{2}$, and $\mathrm{CH}_{3} \mathrm{Br}$ accounts for $24 \mathrm{Gg} \mathrm{Bra}^{-1}$ of tropospheric $\mathrm{Br}_{\mathrm{y}}$. Pyle and Mather (2009) estimated a global volcanic source of $5-15 \mathrm{Gg} \mathrm{Bra}^{-1}$. Photochemical bromine release from sea ice and salt beds can lead to high local concentrations of BrO in surface air (Stutz et al., 2002; Simpson et al., 2007) but the volumes affected are negligible on a global scale.

\subsection{Chemical cycling of $\mathrm{Br}_{\mathrm{y}}$}

Table 2 lists the chemical mechanism for tropospheric bromine in GEOS-Chem. Rate constants, heterogeneous reaction coefficients, and photolysis cross-sections are taken from Sander et al. (2011) unless otherwise specified. Photolysis rates are calculated online with the Fast-J radiative transfer model (Wild et al., 2000). Heterogeneous bromine chemistry in aqueous aerosols includes hydrolysis of $\mathrm{BrNO}_{3}$

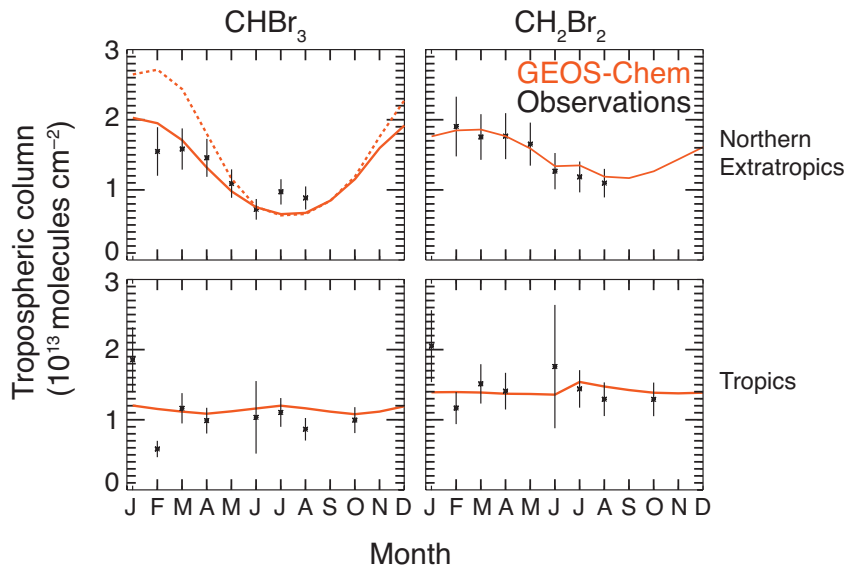

Fig. 2. Comparison of simulated (red) and observed (black) tropospheric columns (molecules $\mathrm{cm}^{-2}$ ) of $\mathrm{CH}_{2} \mathrm{Br}_{2}$ and $\mathrm{CHBr}_{3}$, for the northern extratropics $\left(>30^{\circ} \mathrm{N}\right)$ and the tropics $\left(30^{\circ} \mathrm{S}-30^{\circ} \mathrm{N}\right)$. Column data are integrals of mean vertical profiles up to $10 \mathrm{~km}$ altitude from a compilation of NASA campaigns including STRAT, TRACE-P, INTEX, AVE, TC4, and ARCTAS in the northern extratropics and STRAT, PEM-Tropics, TRACE-P, INTEX, Pre-AVE, AVE, and TC4 in the tropics. References for the observations are in Liang et al. (2010). Vertical bars are the standard deviations in the original data. The dashed red line shows the model results for $\mathrm{CHBr}_{3}$ in the northern extratropics using the original aseasonal emissions from Liang et al. (2010); in order to match the observations in GEOS-Chem we applied seasonal scaling factors to $\mathrm{CHBr}_{3}$ emissions in that region (solid red line).

(Reaction R29) and reaction between $\mathrm{HOBr}$ and $\mathrm{HBr}$ (Reaction R30). Both are treated with a standard reactive uptake probability $(\gamma)$ formulation, resulting in an effective gasphase loss rate constant to a monodisperse aerosol (radius a) given by

$k=\left(\frac{a}{D}+\frac{4}{v \gamma}\right)^{-1} A$

Here $D$ is the molecular diffusion coefficient in air, $v$ is the mean molecular speed of the gas, and $A$ is the aerosol surface area concentration per unit volume of air $\left(\mathrm{cm}^{2} \mathrm{~cm}^{-3}\right.$ ) (Schwartz, 1986; Jacob, 2000). GEOS-Chem simulates explicitly the mass concentrations of different aerosol types, and we integrate $k$ over the prescribed relative humidity-dependent size distributions as described by 
Martin et al. (2002). Reactive uptake probabilities for both Reactions (R29) and (R30) are based on existing laboratory evidence (Table 2d) but with limited information on the sensitivity to temperature and aerosol composition. For $\mathrm{BrNO}_{3}$ hydrolysis Reaction (R29) on liquid cloud droplets, the cloud surface area concentration $A$ is calculated from GEOS-5 liquid water content data, assuming effective droplet radii of $10 \mu \mathrm{m}$ and $6 \mu \mathrm{m}$ for marine and continental clouds respectively (Park et al., 2004; Fu et al., 2008). For $\mathrm{HBr}+\mathrm{HOBr}$ (Reaction R30) on ice cloud surfaces, we use $A=2 \times$ $10^{-4} I^{0.9} \mathrm{~cm}^{2} \mathrm{~cm}^{-3}$ (Lawrence and Crutzen, 1998) applied to the local ice water content $I\left(\mathrm{~cm}^{3} \mathrm{~cm}^{-3}\right)$ from the GEOS-5 data.

Reaction (R30) is an important pathway for recycling bromine radicals in the troposphere (von Glasow et al., 2004; Yang et al., 2010). Although the kinetics are uncertain, there is substantial evidence for this reaction. Abbatt (1995) measured $\gamma>0.25$ for $\mathrm{HBr}+\mathrm{HOBr}$ in sulfuric acid solution $(69 \mathrm{wt} \%)$ with $\mathrm{HBr}$ present in excess. Laboratory measurements show that $\mathrm{HOBr}$ reactive uptake on deliquescent $\mathrm{NaBr}$ and $\mathrm{NaCl}$ aerosol has $\gamma>0.2$ for $\mathrm{pH}<7$ (Abbatt and Waschewsky, 1998; Fickert et al., 1999; Wachsmuth et al., 2002). Fickert et al. (1999) determined the relative production of $\mathrm{Br}_{2}$ vs. $\mathrm{BrCl}$ for $\mathrm{HOBr}$ reacting with aqueous salt solutions containing both $\mathrm{Br}^{-}$and $\mathrm{Cl}^{-}$, and found $\geq 90 \%$ $\mathrm{Br}_{2(\mathrm{~g})}$ production for $\left[\mathrm{Br}^{-}\right] /\left[\mathrm{Cl}^{-}\right]$ratios typical of seawater. Mochida et al. (1998) measured $\gamma=0.18 \pm 0.02$ for $\mathrm{HOBr}$ reactive uptake on solid $\mathrm{KBr}$. On ice surfaces with excess $\mathrm{HBr}$, Abbatt (1994) measured $\gamma=0.12 \pm 0.03$ for $\mathrm{HOBr}+\mathrm{HBr}$ at $228 \mathrm{~K}$, and Chaix et al. (2000) measured $\gamma=0.15 \pm 0.03$ at $205 \mathrm{~K}$. Based on this ensemble of evidence and the recommendation of Sander et al. (2011), we assume that Reaction (R30) proceeds with $\gamma=0.2$ for sulfate and sea salt aerosol (presumed aqueous) and $\gamma=0.1$ for ice surfaces, where $\gamma$ is applied to the locally limiting reactant. This simplified approach assumes that the non-limiting gas is at equilibrium with the aerosol phase.

\subsection{Sinks of $\mathrm{Br}_{\mathrm{y}}$}

Individual $\mathrm{Br}_{\mathrm{y}}$ species are removed by wet and dry deposition. Wet deposition in GEOS-Chem takes place by scavenging in convective updrafts and by in- and below-cloud scavenging from large-scale and convective precipitation (Liu et al., 2001). A standard test for wet deposition in global CTMs is simulation of ${ }^{210} \mathrm{~Pb}$ aerosol, for which the source and atmospheric concentrations are relatively well constrained (Balkanski et al., 1993). Our version of GEOS-Chem yields a tropospheric lifetime of ${ }^{210} \mathrm{~Pb}$ against deposition of 9.5 days (L. T. Murray, personal communication, 2011), consistent with a best observational estimate of 9 days (Liu et al., 2001).

Different gas scavenging efficiencies are used in GEOSChem for warm liquid clouds $(T>268 \mathrm{~K}$ ), mixed clouds $(248<T<268 \mathrm{~K})$, and cold ice clouds $(T<248 \mathrm{~K})$. For warm clouds, partitioning into the aqueous phase is deter- mined by the Henry's law constant (Table 2e) and the liquid volume fraction of the precipitating water. Precipitation in mixed clouds is assumed to take place by riming, and the scavenging efficiency depends on the retention efficiency when the cloud droplets freeze (Stuart and Jacobson, 2003). For $\mathrm{HBr}$ we assume a $100 \%$ riming retention efficiency, following recommendations from Stuart and Jacobson (2003) for gases with large effective Henry's Law constants. For other $\mathrm{Br}_{\mathrm{y}}$ species we assume no retention during riming. We find little sensitivity to the assumed retention efficiency, consistent with previous GEOS-Chem studies for scavenging of ammonia (Wang et al., 2008; Fisher et al., 2010). We assume no scavenging from cold clouds. $\mathrm{HBr}$ and $\mathrm{HOBr}$ undergo heterogeneous chemistry at the surface of ice particles as discussed in Sect. 2.2.

Dry deposition velocities are calculated locally in GEOSChem following a standard resistance-in-series model with surface resistance determined by the Henry's law constant, surface type, and meteorological conditions (Wesely, 1989; Wang et al., 1998). The resulting global annual mean deposition velocities are $0.94 \mathrm{~cm} \mathrm{~s}^{-1}$ for $\mathrm{BrNO}_{3}, 0.93 \mathrm{~cm} \mathrm{~s}^{-1}$ for $\mathrm{HBr}$, and $0.40 \mathrm{~cm} \mathrm{~s}^{-1}$ for $\mathrm{HOBr}$.

\section{Global budget of tropospheric $\mathrm{Br}_{\mathrm{y}}$}

Figure 3 shows the global annual mean budget and cycling of tropospheric $\mathrm{Br}_{\mathrm{y}}$ in our simulation. The $\mathrm{BrO} \mathrm{mx}-$ ing ratio is $0.32 \mathrm{pmol} \mathrm{mol}^{-1}$, which implies a daytime mean of $0.64 \mathrm{pmol} \mathrm{mol}^{-1}$ since nighttime concentrations are near zero. This is at the low end of the oft-cited (but poorly constrained) $0.5-2 \mathrm{pmol} \mathrm{mol}^{-1}$ range in the observations; more detailed comparison with satellite observations will be presented in Sect. 4, and comparison against $\mathrm{BrO}$ observations taken at Cape Verde will be presented by Stone and Evans (2012). The global mean $\mathrm{Br}_{\mathrm{y}}$ mixing ratio is $3.2 \mathrm{pmol} \mathrm{mol}^{-1}$, with $\mathrm{HBr}$ and $\mathrm{HOBr}$ as the principal reservoirs accounting respectively for $34 \%$ and $28 \%$ of total $\mathrm{Br}_{\mathrm{y}}$. $\mathrm{Br}_{\mathrm{y}}$ has a lifetime of 7 days against deposition, with $\mathrm{HBr}$ accounting for $55 \%$ of that sink and $\mathrm{HOBr}$ for $40 \%$. Chemical lifetimes are short relative to deposition; that of $\mathrm{HBr}$ (the longest-lived reservoir) is only $6 \mathrm{~h}$. Thus the $\mathrm{BrO}_{\mathrm{x}}$ radical concentrations are effectively maintained by chemical recycling from non-radical reservoirs.

We see from Fig. 3 that the $\mathrm{HBr}+\mathrm{HOBr}$ heterogeneous Reaction (R30) plays an important role in the recycling of $\mathrm{BrO}_{\mathrm{x}}$ from $\mathrm{HBr}$. A sensitivity simulation without this reaction indicates a factor of 2 decrease in the $\mathrm{BrO}$ mixing ratio to $0.15 \mathrm{pmol} \mathrm{mol}^{-1}$, with $\mathrm{HBr}$ accounting for $70 \%$ of $\mathrm{Br}_{\mathrm{y}}$; the lifetime of $\mathrm{Br}_{\mathrm{y}}$ is shorter in that simulation (5 days) because of the high water solubility of $\mathrm{HBr}$ (Table 2e). The importance of Reaction (R30) reflects the comparable concentrations of $\mathrm{HBr}$ and $\mathrm{HOBr}$ (Fig. 3), as rapid $\mathrm{HOBr}$ production by the $\mathrm{BrO}+\mathrm{HO}_{2}$ Reaction (R18) compensates for the much longer lifetime of $\mathrm{HBr}(6 \mathrm{~h})$ than $\mathrm{HOBr}(20 \mathrm{~min})$. 


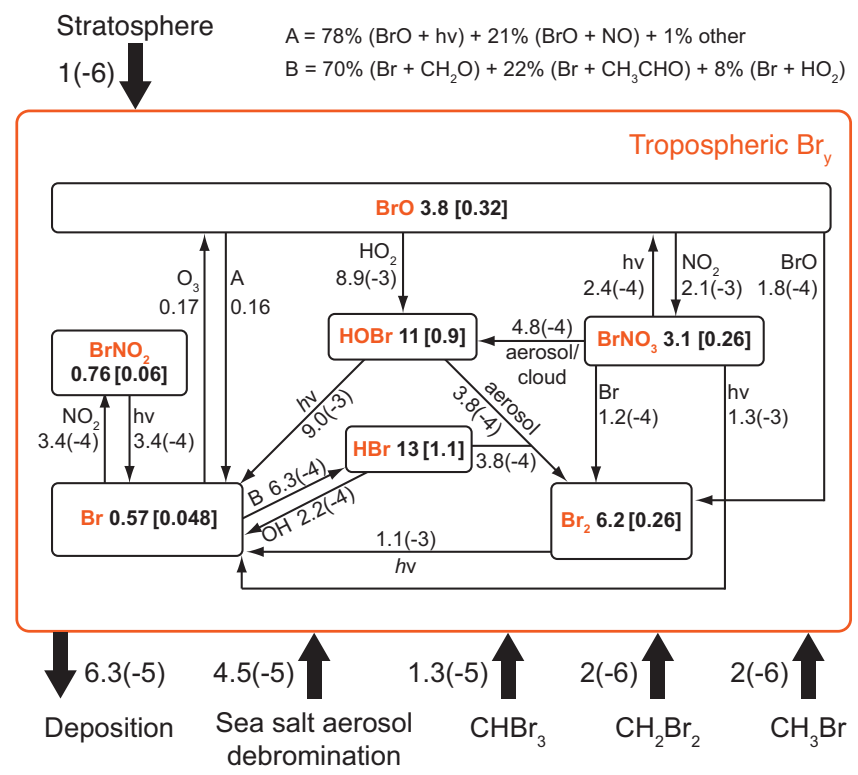

Fig. 3. Global annual mean budget of tropospheric inorganic bromine $\left(\mathrm{Br}_{\mathrm{y}}\right)$ in GEOS-Chem. The main reactions are indicated. Inventories are given as masses $(\mathrm{Gg} \mathrm{Br})$, with mixing ratios $\left(\mathrm{pmol} \mathrm{mol}^{-1}\right)$ in brackets. Rates are given in units of $\mathrm{Gg} \mathrm{Brs}^{-1}$. Read $6.3(-5)$ as $6.3 \times 10^{-5}$. $\mathrm{HBr}$ accounts for $55 \%$ of $\mathrm{Br}_{\mathrm{y}}$ loss by deposition. Sea-salt aerosol debromination is the dominant global source of $\mathrm{Br}_{\mathrm{y}}$ but is mainly confined to the marine boundary layer where $\mathrm{Br}_{\mathrm{y}}$ has a short lifetime against deposition. It accounts for $48 \%$ of the $\mathrm{Br}_{\mathrm{y}}$ source in the global free troposphere.

Figure 4 shows the zonal annual mean $\mathrm{BrO}, \mathrm{Br}$, and $\mathrm{Br}_{\mathrm{y}}$ mixing ratios in the model. The highest concentrations of $\mathrm{Br}_{\mathrm{y}}$ and $\mathrm{BrO}$ are in the marine boundary layer at southern mid-latitudes due to the large source from sea-salt aerosol debromination. In the rest of the troposphere $\mathrm{Br}_{\mathrm{y}}$ is relatively uniform $\left(2-4 \mathrm{pmol} \mathrm{mol}^{-1}\right)$, with a minimum in the tropical upper troposphere due to scavenging in convective updrafts. Mixing ratios increase with altitude in the stratosphere where the boundary conditions from Liang et al. (2010) are applied.

$\mathrm{BrO}$ and $\mathrm{Br}$ concentrations in Fig. 4 show a general increase with altitude, and $\mathrm{BrO}$ shows in addition an increase with latitude. The budget of $\mathrm{BrO}$ is largely that of $\mathrm{BrO}_{\mathrm{x}}$ since $[\mathrm{BrO}] \gg[\mathrm{Br}]$. From Fig. 3 we see that the dominant sink of $\mathrm{BrO}_{\mathrm{x}}$ is the $\mathrm{BrO}+\mathrm{HO}_{2}$ Reaction (R18), which is fastest in the tropical lower troposphere where $\mathrm{HO}_{2}$ concentrations are highest. The dominant source of $\mathrm{Br}$ is photolysis of $\mathrm{BrO}$ (Fig. 3), which cancels the latitudinal dependence of $\mathrm{BrO}$ concentrations and drives the strong increase of $\mathrm{Br}$ concentrations with altitude.

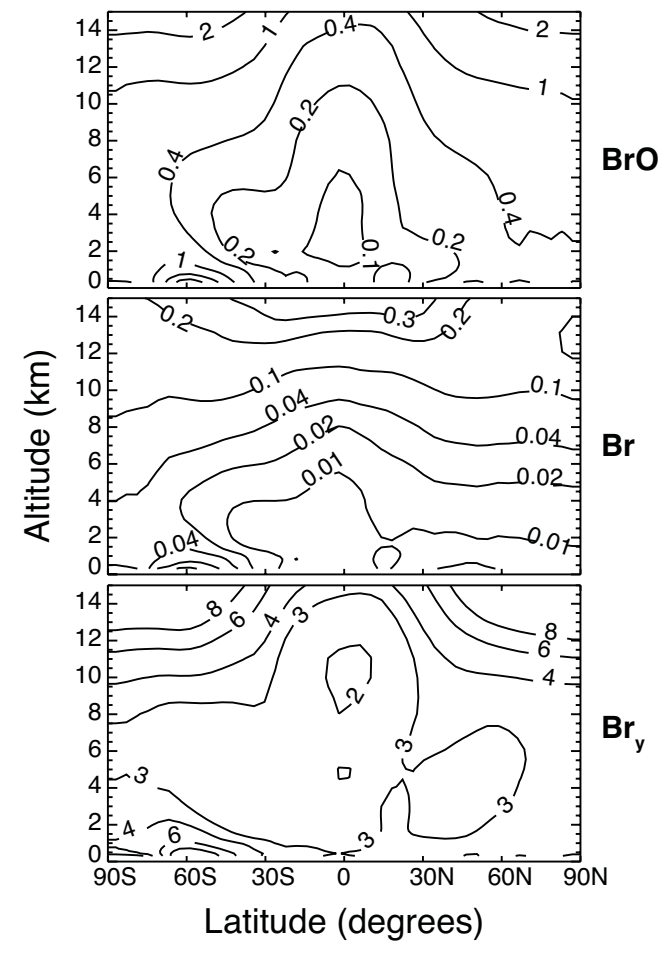

Fig. 4. Zonal annual mean concentrations ( $\mathrm{pmol} \mathrm{mol}^{-1}$ ) of $\mathrm{BrO}, \mathrm{Br}$, and $\mathrm{Br}_{\mathrm{y}}$ in GEOS-Chem.

\section{Comparison to satellite observations of tropospheric BrO}

Figure 5 compares simulated $\mathrm{BrO}$ tropospheric columns to a GOME-2 satellite data set retrieved by Theys et al. (2011) with monthly resolution for 2007 and for six latitudinal bands. Theys et al. (2011) fitted total slant columns of $\mathrm{BrO}$ to the solar backscattered radiation spectra. They then removed the stratospheric contribution by using correlations of stratospheric $\mathrm{BrO}$ with ozone and $\mathrm{NO}_{2}$ from the BASCOE 3D-CTM (Theys et al., 2009) and applying these correlations to the local GOME-2 observations of ozone and stratospheric $\mathrm{NO}_{2}$ columns. They converted the tropospheric slant columns to vertical columns with an air mass factor assuming a Gaussian-shaped vertical distribution of $\mathrm{BrO}$ peaking at $6 \mathrm{~km}$ altitude. The grey shading in Fig. 5 indicates the total observational error estimated by Theys et al. (2011), including contributions from the air mass factor, surface albedo, cloud fractions, stratospheric BrO column removal, and cloud top heights.

The GOME-2 data are for $\sim 09: 30$ local time (LT) and we sample GEOS-Chem at 09:00-11:00 LT for comparison. GEOS-Chem data in Fig. 5 include both the actual tropospheric vertical columns (red) and the columns corrected for the Theys et al. (2011) air mass factors using their tabulated scattering weights including for partly cloudy scenes. The correction is uncertain because the tabulation of scattering 
weights is sparse, but the effect is relatively small except at southern mid-latitudes where the model $\mathrm{BrO}$ has a large contribution from the boundary layer. Also shown in Fig. 5 are actual tropospheric vertical columns sampled at 09:0011:00 LT from the p-TOMCAT CTM bromine simulation of Yang et al. (2010), (blue) and from GEOS-Chem without the $\mathrm{HBr}+\mathrm{HOBr}$ Reaction (R30) (dashed). p-TOMCAT and GEOS-Chem have completely different heritages. Specific differences in the $\mathrm{p}$-TOMCAT simulation of bromine include the use of a smaller rate constant for $\mathrm{HBr}+\operatorname{HOBr}(\gamma=0.02$ instead of 0.2 , and no reaction on cloud ice particles), and consideration of a blowing snow source in polar regions during spring.

The standard GEOS-Chem simulation underestimates the GOME- 2 observations by $30 \%$ on a global mean basis, excluding the poles $(40 \%$ including the air mass factor correction). This is marginally significant considering the observation error but might indicate a low bias in the simulated emissions or heterogeneous recycling of $\mathrm{Br}_{\mathrm{y}}$. The observations show a positive $\mathrm{BrO}$ gradient with increasing latitude that is well reproduced in GEOS-Chem contingent on the (Reaction $\mathrm{R} 30) \mathrm{HBr}+\mathrm{HOBr}$ reaction. Although Reaction (R30) is a photochemical pathway inasmuch as $\mathrm{HOBr}$ and $\mathrm{HBr}$ are mainly produced photochemically, it is most effective when radiation is weak since aerosol uptake of $\mathrm{HOBr}$ competes with $\mathrm{HOBr}$ photolysis. Thus the effect of Reaction (R30) for $\mathrm{BrO}_{\mathrm{x}}$ recycling is relatively small in the tropics but very large in the extratropics. It has a strong effect on seasonality in the extratropics, enabling GEOS-Chem to reproduce the observed winter maximum at northern mid-latitudes, in contrast to p-TOMCAT where Reaction (R30) is less important due to a seasonally constant non-sea salt aerosol loading and lower $\gamma$.

We conducted several sensitivity simulations to examine if uncertainties in gas-phase bromine kinetics as estimated by Sander et al. (2011) could account for the $30 \%$ global model underestimate of $\mathrm{BrO}$ relative to the Theys et al. (2011) data. We found the effects to be relatively small. The largest response was from the $\mathrm{Br}+\mathrm{CH}_{2} \mathrm{O}$ Reaction (R5). Decreasing the pre-exponential factor for that reaction by $30 \%$ and increasing the activation energy by $30 \%$ (error standard deviations from Sander et al., 2011) resulted in a $19 \%$ global increase in simulated $\mathrm{BrO}$.

A major feature in the $\mathrm{BrO}$ observations of Theys et al. (2011) is the strong Arctic spring maximum. This is reproduced by both GEOS-Chem and p-TOMCAT but for different reasons. In GEOS-Chem it is due mainly to fast $\mathrm{HBr}+\mathrm{HOBr}$ recycling (Reaction $\mathrm{R} 30)\left(\gamma_{\mathrm{HOBr}}=0.2\right.$ in GEOS-Chem compared to $\gamma_{\mathrm{HOBr}}=0.02$ in p-TOMCAT for aqueous aerosol), with no springtime emissions of $\mathrm{Br}_{\mathrm{y}}$ from sea ice. The spring shift in GEOS-Chem (relative to the winter maximum at northern mid-latitudes) is due to the need for some insolation to drive $\mathrm{HOBr}$ production. $\mathrm{p}$-TOMCAT simulates a spring maximum with slower $\mathrm{HBr}+\mathrm{HOBr}$ recycling by including a blowing-snow source for $\mathrm{Br}_{\mathrm{y}}$ (Yang

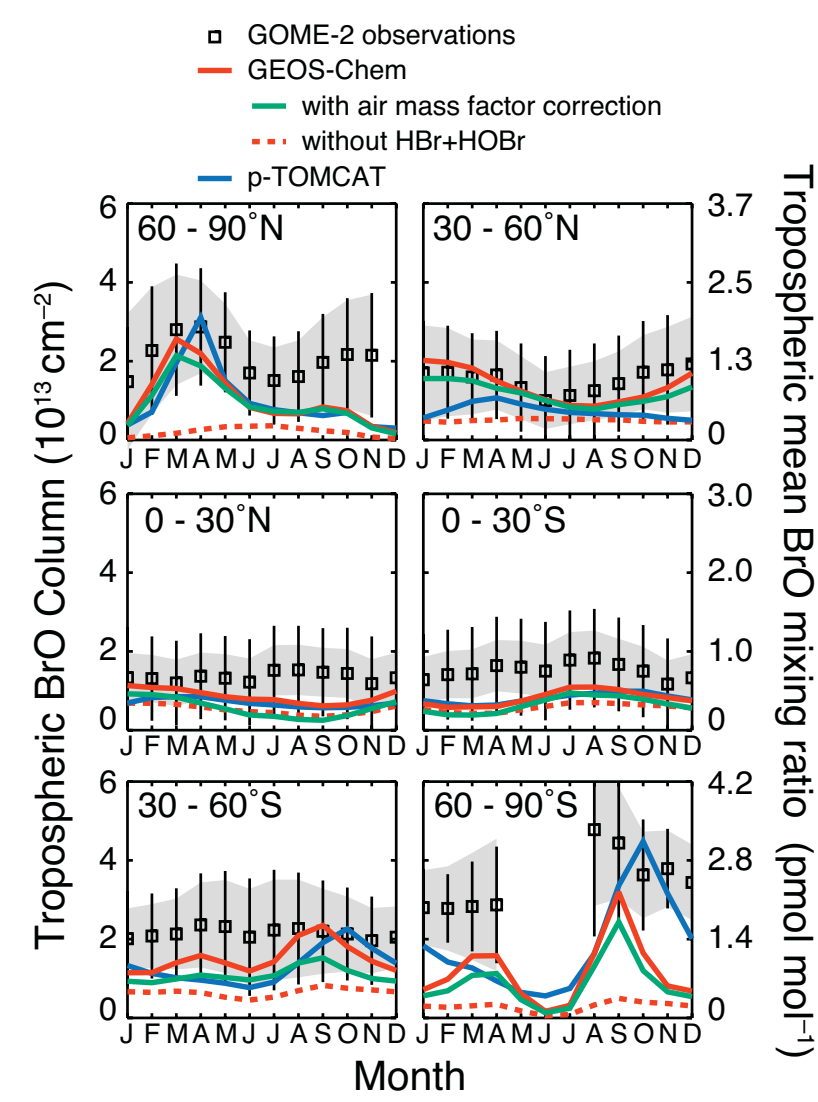

Fig. 5. Seasonal variation of mean tropospheric $\mathrm{BrO}$ columns in different latitudinal bands. GOME-2 observations from Theys et al. (2011) are compared to model values from GEOS-Chem and from p-TOMCAT (Yang et al., 2010). GEOS-Chem values are shown for the actual vertical columns (red) and for vertical columns corrected by the GOME-2 air mass factors (green). Also shown are results from a sensitivity simulation without the $\mathrm{HBr}+\mathrm{HOBr}$ heterogeneous Reaction (R30). p-TOMCAT values are actual vertical columns. The models were sampled at 09:00-11:00 local time (LT), corresponding to the GOME-2 viewing time of $\sim 09: 30$ LT. Grey shading shows the observational error on the means reported by Theys et al. (2011) and vertical bars indicate one standard deviation of their spatial averaging. The $\mathrm{BrO}$ mixing ratios on the right axis scale are derived from the $\mathrm{BrO}$ columns by dividing by the annual mean tropospheric air density columns for the corresponding latitude bin in GEOS-Chem.

et al., 2008, 2010). The Arctic column amounts in GEOSChem are dominated by the free troposphere, while those in p-TOMCAT have a large boundary layer contribution. In-situ observations of $\mathrm{BrO}$ during the ARCTAS aircraft campaign over Alaska in April 2008 found significant mixing ratios in the free troposphere, with a mean of $\sim 2 \mathrm{pmol} \mathrm{mol}^{-1}$ (Salawitch et al., 2010). In comparison, GEOS-Chem simulates a 09:00-17:00 LT mean of $1.3 \mathrm{pmol} \mathrm{mol}^{-1} \mathrm{BrO}$ for the Arctic free troposphere in April. Both models likely oversimplify photochemistry in polar spring, as local emissions of 
$\mathrm{Br}_{\mathrm{y}}$ and the extent of heterogeneous recycling remain poorly constrained (Simpson et al., 2007).

Figure 5 shows little seasonal variation of $\mathrm{BrO}$ column in the tropics, either in the observations or the models. The models are too low. Observations at southern midlatitudes show concentrations comparable to northern midlatitudes (confirming the dominant natural origin of $\mathrm{Br}_{\mathrm{y}}$ ) but weaker seasonal dependence as might be expected from lower aerosol concentrations to drive (Reaction R30).

\section{Impact on tropospheric ozone and $\mathrm{OH}$}

Tropospheric bromine chemistry drives several catalytic cycles for ozone loss in the troposphere. The three most important are:

Mechanism 1: $\mathrm{BrO}+\mathrm{HO}_{2}$

$$
\begin{aligned}
& \mathrm{Br}+\mathrm{O}_{3} \longrightarrow \mathrm{BrO}+\mathrm{O}_{2} \\
& \mathrm{BrO}+\mathrm{HO}_{2} \longrightarrow \mathrm{HOBr}+\mathrm{O}_{2} \\
& \mathrm{HOBr}+h v \longrightarrow \mathrm{Br}+\mathrm{OH} \\
& \text { net: } \mathrm{O}_{3}+\mathrm{HO}_{2} \longrightarrow \mathrm{OH}+2 \mathrm{O}_{2}
\end{aligned}
$$

with closure for the hydrogen oxide radicals $\left(\mathrm{HO}_{\mathrm{x}} \equiv \mathrm{OH}+\right.$ $\mathrm{H}+\mathrm{HO}_{2}+$ organic peroxy and oxy radicals) provided for example by oxidation of $\mathrm{CO}$,

$$
\begin{aligned}
& \mathrm{CO}+\mathrm{OH} \stackrel{\mathrm{O}_{2}}{\longrightarrow} \mathrm{CO}_{2}+\mathrm{HO}_{2} . \\
& \text { Mechanism 2: } \mathrm{BrNO}_{3}+\mathrm{H}_{2} \mathrm{O} \\
& \mathrm{Br}+\mathrm{O}_{3} \longrightarrow \mathrm{BrO}+\mathrm{O}_{2} \\
& \mathrm{BrO}+\mathrm{NO}_{2}+\mathrm{M} \longrightarrow \mathrm{BrNO}_{3}+\mathrm{M} \\
& \mathrm{BrNO}_{3} \stackrel{\mathrm{H}_{2} \mathrm{O}, \text { aerosol }}{\longrightarrow} \mathrm{HOBr}+\mathrm{HNO}_{3} \\
& \mathrm{HOBr}+h v \longrightarrow \mathrm{Br}+\mathrm{OH}
\end{aligned}
$$$$
\text { net: } \mathrm{O}_{3}+\mathrm{NO}_{2}+\mathrm{H}_{2} \mathrm{O}_{(\mathrm{aq})} \longrightarrow \mathrm{O}_{2}+\mathrm{HNO}_{3}+\mathrm{OH} \text {. }
$$

Mechanism 3: $\mathrm{HOBr}+\mathrm{HBr}$

$$
\begin{aligned}
& \mathrm{Br}+\mathrm{O}_{3} \longrightarrow \mathrm{BrO}+\mathrm{O}_{2} \\
& \mathrm{BrO}+\mathrm{HO}_{2} \longrightarrow \mathrm{HOBr}+\mathrm{O}_{2} \\
& \mathrm{Br}+\mathrm{RH} \stackrel{\mathrm{O}_{2}}{\longrightarrow} \mathrm{HBr}+\mathrm{RO}_{2} \\
& \mathrm{HOBr}+\mathrm{HBr} \stackrel{\text { aerosol or ice }}{\longrightarrow} \mathrm{Br}_{2}+\mathrm{H}_{2} \mathrm{O} \\
& \mathrm{Br} 2+h v \longrightarrow 2 \mathrm{Br} \\
& \text { net }: \quad \mathrm{O}_{3}+\mathrm{HO}_{2}+\mathrm{RH} \longrightarrow \mathrm{O}_{2}+\mathrm{H}_{2} \mathrm{O}+\mathrm{RO}_{2} .
\end{aligned}
$$

A common step in all three mechanisms is the formation of $\mathrm{HOBr}$. Loss of $\mathrm{HOBr}$ is either by photolysis or by reaction with $\mathrm{HBr}$ (Fig. 3), and both of these sinks drive catalytic ozone loss (Mechanisms 1 and 3). Thus Br-catalyzed ozone loss is limited by the rate of HOBr production. This is in contrast to the polar springtime boundary layer, where the
$\mathrm{BrO}+\mathrm{BrO}$ self-reaction is the dominant catalytic ozone sink due to very high $\mathrm{BrO}$ concentrations. We see from Fig. 3 that the self-reaction of $\mathrm{BrO}$ is 50 times slower than the reaction with $\mathrm{HO}_{2}$ on the global scale. The $\mathrm{BrO}+\mathrm{HO}_{2}$ Reaction (R14) accounts for $95 \%$ of global tropospheric $\mathrm{HOBr}$ production while $\mathrm{BrNO}_{3}$ hydrolysis accounts for the rest. Since $92 \%$ of $\mathrm{HOBr}$ is photolyzed, Mechanism 1 is responsible for about $90 \%$ of Br-catalyzed ozone loss. However, Mechanism 2 has the important secondary effect of providing a sink for $\mathrm{NO}_{\mathrm{x}}$ and thus slowing down ozone production.

Table 3 shows the global impact of bromine chemistry on the tropospheric ozone budget. The budget is calculated following standard procedure as that of the odd oxygen family $\mathrm{O}_{\mathrm{x}} \equiv \mathrm{O}_{3}+\mathrm{NO}_{2}+2 \mathrm{NO}_{3}+$ peroxyacylnitrates $+\mathrm{HNO}_{4}+3 \mathrm{~N}_{2} \mathrm{O}_{5}+\mathrm{HNO}_{3}+\mathrm{BrO}+\mathrm{BrNO}_{2}+2 \mathrm{BrNO}_{3}$ (Crutzen and Schmailzl, 1983; Wu et al., 2007) to account for fast cycling of minor species with ozone. The tropospheric production rate of ozone in GEOS-Chem decreases by $4.1 \%$ when bromine chemistry is included, and the ozone lifetime decreases by $2.9 \%$. We find a $6.5 \%$ decrease in the global tropospheric ozone burden. A previous model study by von Glasow et al. (2004) found a larger (10-15\%) effect of bromine chemistry on the tropospheric ozone budget because they imposed higher bromine concentrations. Yang et al. (2010) found bromine to decrease the ozone burden by $25.5 \mathrm{Tg}(8.6 \%)$, close to our result of $24 \mathrm{Tg}(6.5 \%)$.

We see from Table 3 that bromine chemistry also causes a $4 \%$ decrease in the global concentration of $\mathrm{OH}$, the main tropospheric oxidant. This appears to mainly reflect the decreases in ozone and $\mathrm{NO}_{\mathrm{x}}$, and is partly compensated by the source of $\mathrm{OH}$ from Mechanism 2. Applying our global mean fields of $\mathrm{OH}$ and temperature with kinetics from Sander et al. (2011), we calculate a methylchloroform tropospheric lifetime against oxidation by OH in GEOS-Chem of $4.79 \mathrm{yr}$ with bromine and $4.65 \mathrm{yr}$ without. Though both are shorter than estimates from observations, 5.5 to $6 \mathrm{yr}$ (Spivakovsky et al., 2000; Prinn et al., 2005), bromine decreases the model bias. Fast conversion of $\mathrm{HO}_{2}$ to $\mathrm{H}_{2} \mathrm{O}$ in aerosols, not included in our GEOS-Chem version, could fully correct the bias (Mao et al., 2010, 2012).

Figure 6 shows the seasonal zonal mean decreases in tropospheric ozone mixing ratios due to bromine chemistry. Concentrations decrease by $<1-8 \mathrm{nmol} \mathrm{mol}^{-1}$ depending on region and season. The impact is largest in the northern extratropics in spring, reflecting a combination of elevated $\mathrm{BrO}$ (Fig. 5) and ozone. The general increase with latitude in the effect of bromine on ozone is consistent with the previous model studies of von Glasow et al. (2004) and Yang et al. (2010). We find little zonal variability in the effect.

A number of studies have previously evaluated the global ozone simulation in GEOS-Chem with observations from surface sites, sondes, and satellites (Sauvage et al., 2007; Nassar et al., 2009; Zhang et al., 2010). These have shown patterns of over- and underestimates that can vary 
Table 3. Global tropospheric ozone $\left(\mathrm{O}_{\mathrm{x}}\right)$ budget in GEOS-Chem ${ }^{\mathrm{a}}$.

\begin{tabular}{lccccccc}
\hline & $\begin{array}{c}\text { Chemical production, } \\
P\left(\mathrm{O}_{\mathrm{x}}\right) \\
\mathrm{Tg} \mathrm{a}^{-1}\end{array}$ & $\begin{array}{c}\text { Chemical loss, } \\
L\left(\mathrm{O}_{\mathrm{x}}\right) \\
\mathrm{Tg} \mathrm{a}^{-1}\end{array}$ & $\begin{array}{c}\text { Deposition } \\
\mathrm{Tg} \mathrm{a}^{-1}\end{array}$ & $\mathrm{STE}^{\mathrm{b}}$ & $\begin{array}{c}\text { Tropospheric } \\
\mathrm{Tg} \mathrm{a}^{-1}\end{array}$ & $\begin{array}{c}\text { Lifetime } \\
\mathrm{Tg}\end{array}$ & days $^{[\mathrm{OH}]}$ \\
\hline No bromine & 5110 & 4480 & 948 & 349 & 370 & 27.8 & 1.23 \\
With bromine & 4910 & 4350 & 879 & 355 & 346 & 27.0 & 1.18 \\
\hline
\end{tabular}

a Global annual mean budget for the odd oxygen $\left(\mathrm{O}_{\mathrm{x}}\right)$ chemical family defined as $\mathrm{O}_{\mathrm{x}} \equiv \mathrm{O}_{3}+\mathrm{NO}_{2}+2 \mathrm{NO}_{3}+$ peroxyacylnitrates $+\mathrm{HNO}_{4}+3 \mathrm{~N}_{2} \mathrm{O}_{5}+\mathrm{HNO}_{3}+\mathrm{BrO}+\mathrm{BrNO}_{2}+$ $2 \mathrm{BrNO}_{3}$ (Crutzen and Schmailzl, 1983; Wu et al., 2007), with molecular weight taken to be that of ozone.

b Stratosphere-to-troposphere exchange is inferred from mass-balance: $\mathrm{STE}=L\left(\mathrm{O}_{\mathrm{x}}\right)+$ Deposition $-P\left(\mathrm{O}_{\mathrm{x}}\right)$.

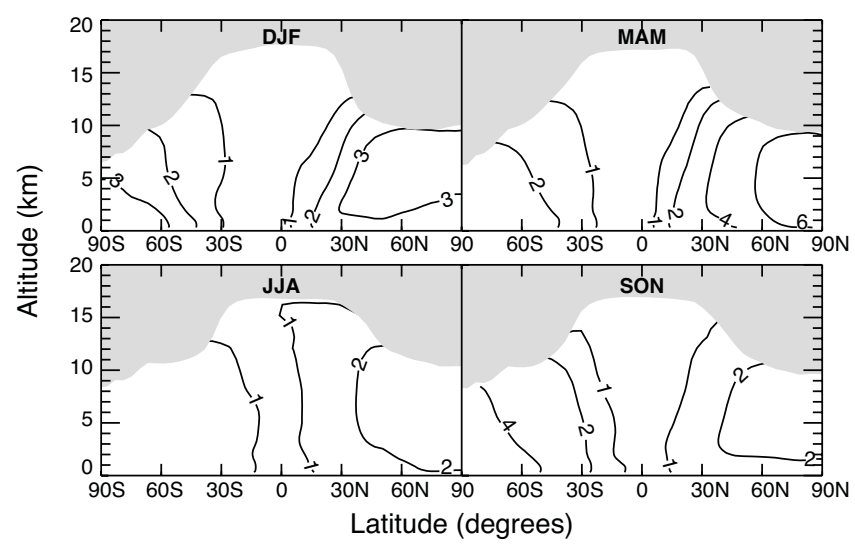

Fig. 6. Decrease in tropospheric ozone $\left(\mathrm{nmol} \mathrm{mol}^{-1}\right)$ from bromine chemistry. The figure shows zonal seasonal mean differences between GEOS-Chem simulations including vs. not including bromine chemistry. Shading indicates the stratosphere.

significantly in successive model versions due to changes in model emissions, chemistry, and transport (Wu et al., 2007). Zhang et al. (2010) presented an extensive global comparison to ozonesonde and satellite measurements using a version of GEOS-Chem similar to ours (v8-02-03). They found that the model was too high in southern mid-latitudes and the northern subtropics but too low in the tropics, with negligible bias in the northern extratropics. Adding bromine chemistry in that simulation would produce mixed results in comparisons to observations. However, the latest version of GEOS-Chem (v9; http://www.geos-chem.org) includes improved isoprene chemistry that corrects the ozone bias in the tropics but drives a systematic model overestimate of $5-10 \mathrm{nmol} \mathrm{mol}^{-1}$ in the northern extratropics (Paulot et al., 2009a, b). Including bromine chemistry in that latest version could largely correct the discrepancy in the extratropics and this will need to be investigated in future work.

\section{Impact on pre-industrial ozone and radiative forcing}

A long-standing problem in global modeling of tropospheric ozone has been the inability of models to reproduce the very low ozone concentrations measured in surface air worldwide

\section{Montsouris, France (1876 - 1886)}

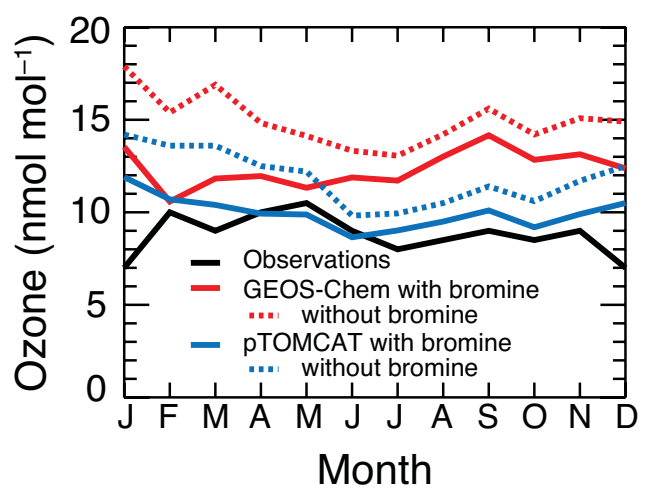

Fig. 7. Mean seasonal variation of 19th-century ozone in surface air at Montsouris, France $\left(50^{\circ} \mathrm{N}, 2^{\circ} \mathrm{E}\right)$. 1876-1886 observations reanalyzed by Volz and Kley (1988) (black) are compared to preindustrial model simulations using GEOS-Chem (red) and p-TOMCAT (blue), with bromine chemistry (solid) and without (dotted).

at the turn of the 20th century (Wang and Jacob, 1998; Mickley et al., 2001; Shindell et al., 2003; Lamarque et al., 2005; Horowitz, 2006). Calibration of these older measurements is controversial (Marenco et al., 1994) but the Montsouris (Paris) measurements are considered reliable (Volz and Kley, 1988). To examine the potential for bromine chemistry to address this discrepancy we conducted a GEOS-Chem sensitivity simulation for the pre-industrial atmosphere removing all anthropogenic sources (including $\mathrm{NO}_{\mathrm{x}}$ from fertilizer use), and reducing methane from 1700 to $700 \mathrm{nmol} \mathrm{mol}^{-1}$. We decreased biomass burning to $10 \%$ of its present value (Wang and Jacob, 1998), though this has little impact on our results. Bromine sources were held to present-day estimates, except for $\mathrm{CH}_{3} \mathrm{Br}$ and the stratospheric boundary condition. We used $5 \mathrm{pmol} \mathrm{mol}^{-1} \mathrm{CHBr}_{3}$ in surface air worldwide based on ice core records (Saltzman et al., 2004). Mixing ratios of stratospheric $\mathrm{Br}_{\mathrm{y}}$ species were scaled from a total of 22 to 12 pmol mol ${ }^{-1} \mathrm{Br}_{\mathrm{y}}$ (Liang et al., 2010; Montzka et al., 2011). Sea salt debromination rates may have increased between the preindustrial and present-day due to enhanced particle acidity from anthropogenic emissions (Sander et al., 2003) but this effect is not considered here. 
Figure 7 compares the 1876-1886 Montsouris observations to simulated pre-industrial ozone from GEOS-Chem and p-TOMCAT (Yang et al., 2010), with and without bromine chemistry. p-TOMCAT applies similar conditions to GEOS-Chem for simulating the pre-industrial atmosphere. The simulations without bromine chemistry overestimate the mean observed ozone by 6.2 and $3.1 \mathrm{nmol} \mathrm{mol}^{-1}$ in GEOS-Chem and p-TOMCAT respectively. Both simulations show a seasonal maximum in late winter and early spring, which is a standard extratropical feature in models of natural ozone (Wang and Jacob, 1998; Monks, 2000; Mickley et al., 2001) but is not seen in the Montsouris observations. Including bromine chemistry decreases annual mean ozone at Montsouris by 2.6 and $1.9 \mathrm{nmol} \mathrm{mol}^{-1}$ in GEOS-Chem and p-TOMCAT, respectively, effectively correcting the overestimate in p-TOMCAT and reducing it substantially in GEOS-Chem. The decrease is least in summer $\left(0.9-1.4 \mathrm{nmol} \mathrm{mol}^{-1}\right)$ and greatest in winter-spring (2.3$5.1 \mathrm{nmol} \mathrm{mol}^{-1}$ ), which suppresses the winter-spring maximum in both models. Although there are significant differences in simulated ozone between GEOS-Chem and pTOMCAT, the impact of bromine chemistry on both models is consistent.

Saiz-Lopez et al. (2012) recently suggested that halogen chemistry could reduce the radiative forcing from anthropogenic tropospheric ozone since pre-industrial times by $-0.1 \mathrm{~W} \mathrm{~m}^{-2}$ or about $30 \%$. However, they only considered the impact of this chemistry on the present-day atmosphere. Considering that tropospheric halogens are mainly natural, they would also decrease ozone in the pre-industrial atmosphere. We find in GEOS-Chem that although the sources of bromine are similar in the present and pre-industrial atmospheres, the chemistry differs in two principal ways. First, lower methane in the pre-industrial atmosphere leads to lower $\mathrm{CH}_{2} \mathrm{O}$ and hence suppressed production of $\mathrm{HBr}$ by Reaction (R5). Second, lower aerosol loadings suppress the $\mathrm{HBr}+\mathrm{HOBr}$ heterogeneous Reaction (R30). These two effects have competing influences on tropospheric $\mathrm{BrO}$ and we find in GEOS-Chem that they largely cancel. Thus the effects of bromine chemistry on ozone are similar in the present-day and pre-industrial atmospheres. We find that the increases in the total tropospheric ozone burden from pre-industrial to present are 119 and $113 \mathrm{Tg}$ in the simulations without and with bromine chemistry, respectively. Considering that the radiative forcing from tropospheric ozone depends roughly linearly on the change in burden (Mickley et al., 1999), we conclude that bromine chemistry decreases ozone radiative forcing by about $5 \%$.

The impact of bromine chemistry on pre-industrial US surface ozone is of interest because this natural background represents a policy reference point for assessing the risk associated with anthropogenic emissions (US Environmental Protection Agency, 2006). Zhang et al. (2010) recently reported a mean natural ozone background in US surface air of $18 \pm 6 \mathrm{nmol} \mathrm{mol}^{-1}$ using a high-resolution version of
GEOS-Chem. We find in our simulation that bromine chemistry decreases natural surface ozone over the US from 16 to $13 \mathrm{nmol} \mathrm{mol}^{-1}$ on an annual mean basis, i.e., an effect of $3 \mathrm{nmol} \mathrm{mol}^{-1}$ or $19 \%$.

\section{Implications for the atmospheric lifetime of mercury}

Mercury in the atmosphere is mostly emitted as gaseous $\mathrm{Hg}(0)$, and is removed by oxidation followed by rapid deposition of the water-soluble $\mathrm{Hg}$ (II) compounds (Lindberg et al., 2007). The observed atmospheric variability of $\mathrm{Hg}(0) \mathrm{im}$ plies a lifetime against deposition of $0.5-1 \mathrm{yr}$, with a possibly shorter lifetime against oxidation depending on whether atmospheric $\mathrm{Hg}$ (II) can be reduced back to $\mathrm{Hg}(0)$ (Slemr et al., 1981, 1985; Bergan et al., 1999; Holmes et al., 2010). Most models of atmospheric mercury have assumed that oxidation of $\mathrm{Hg}(0)$ is driven by $\mathrm{OH}$ and ozone, but these reactions are now thought to be too slow to be of atmospheric relevance (Calvert and Lindberg, 2005; Hynes et al., 2009). Goodsite et al. (2004) showed that rapid oxidation of $\mathrm{Hg}(0)$ to $\mathrm{Hg}$ (II) by $\mathrm{Br}$ atoms could take place by

$$
\begin{aligned}
& \mathrm{Hg}+\mathrm{Br}+\mathrm{M} \longrightarrow \mathrm{HgBr}+\mathrm{M} \\
& \mathrm{HgBr} \stackrel{\mathrm{M}}{\rightarrow} \mathrm{Hg}+\mathrm{Br} \\
& \mathrm{HgBr}+\mathrm{X} \stackrel{\mathrm{M}}{\rightarrow} \mathrm{HgBrX},
\end{aligned}
$$

where $\mathrm{X}$ is a radical, such as $\mathrm{OH}$ or $\mathrm{Br}$, that converts unstable $\mathrm{Hg}(\mathrm{I})$ to stable $\mathrm{Hg}(\mathrm{II})$ in a 3-body reaction. Under tropospheric conditions, Reaction (R31) operates in the lowpressure limit whereas Reaction (R33) operates in the highpressure limit (Goodsite et al., 2004, 2012; Donohoue et al., 2006). Using the kinetic data from Goodsite et al. (2004) and Donohue et al. (2006), together with $\mathrm{Br}$ concentration fields from the p-TOMCAT model (Yang et al., 2005) and OH fields from GEOS-Chem, Holmes et al. (2006, 2010) showed that oxidation by $\mathrm{Br}$ atoms could represent the dominant global atmospheric sink for $\mathrm{Hg}(0)$. Here we revisit this calculation using our computed $\mathrm{Br}$ concentrations and draw implications for possible changes in the $\operatorname{Hg}(0)$ atmospheric lifetime between pre-industrial and present conditions.

The lifetime $\tau$ of $\mathrm{Hg}(0)$ against oxidation to $\mathrm{Hg}(\mathrm{II})$ by Reactions (R31)-(R33) can be expressed assuming $\mathrm{HgBr}$ steady state by Holmes et al. (2006):

$$
\tau=\frac{k_{32}+k_{33, \mathrm{Br}}[\mathrm{Br}]+k_{33, \mathrm{OH}}[\mathrm{OH}]}{k_{31}[\mathrm{Br}][\mathrm{M}]\left(k_{33, \mathrm{Br}}[\mathrm{Br}]+k_{33, \mathrm{OH}}[\mathrm{OH}]\right)},
$$

where we have assumed that $\mathrm{X}$ in Reaction (R33) can be either $\mathrm{Br}$ or $\mathrm{OH}$, following Holmes et al. (2006, 2010). Using the kinetic data of Holmes et al. (2010) with updates from Goodsite et al. (2012), and assuming a uniform tropospheric $\mathrm{Hg}(0)$ concentration, we derive from our GEOS-Chem model fields a global tropospheric $\mathrm{Hg}(0)$ lifetime of $0.58 \mathrm{yr}$ against oxidation by Br. In comparison, Holmes et al. (2010) calculated a lifetime of $0.50 \mathrm{yr}$ in a GEOS-Chem $\mathrm{Hg}(0)$ simulation 
using the Yang et al. (2005) Br mixing ratios in the free troposphere and assuming $1 \mathrm{pmol} \mathrm{mol}^{-1} \mathrm{BrO}$ in the marine boundary layer. We repeated our calculation using their archived $\mathrm{Br}$ and $\mathrm{OH}$ fields and obtain a lifetime of $0.41 \mathrm{yr}$ with the Holmes et al. (2010) kinetics, and $0.65 \mathrm{yr}$ with the kinetics update from Goodsite et al. (2012). Our estimate of $0.41 \mathrm{yr}$ can be viewed as consistent with the Holmes et al. (2010) estimate of $0.50 \mathrm{yr}$ in view of the uncertainty involved with assuming a uniform $\mathrm{Hg}(0)$ concentration. Our $11 \%$ shorter lifetime $(0.58$ vs. $0.65 \mathrm{yr})$ reflects a $13 \%$ greater mean tropospheric $\mathrm{Br}$ concentration in our GEOS-Chem simulation.

The mean tropospheric $\mathrm{Br}$ atom concentration in our preindustrial simulation is $38 \%$ greater than present-day due to lower ozone suppressing the $\mathrm{Br}+\mathrm{O}_{3}$ Reaction (R4). This increase in $\mathrm{Br}$ causes the $\mathrm{Hg}(0)$ lifetime against oxidation to decrease to $0.35 \mathrm{yr}, 40 \%$ lower than present-day. Our work thus suggests that the increase in ozone since pre-industrial times may have increased the atmospheric residence time of $\mathrm{Hg}(0)$ by $66 \%$. With an atmospheric lifetime of four months, mercury in pre-industrial times would be less of a global pollutant than today. Most of the observed increase in ozone has taken place since 1950 (Marenco et al., 1994), by which time there had already been large anthropogenic mercury emissions at northern mid-latitudes from mining, industry, and combustion (Streets et al., 2011).

Our work highlights a potentially important link between ozone trends and the lifetime of $\mathrm{Hg}(0)$ through partitioning of the $\mathrm{Br}_{\mathrm{y}}$ family. This result is contingent on $\mathrm{Br}$ playing a dominant role in $\operatorname{Hg}(0)$ oxidation. Changes in sea salt debromination between the preindustrial and present as well as our simplified treatment of heterogeneous bromine chemistry represent additional uncertainties that might affect our $\mathrm{Hg}(0)$ lifetime estimates.

\section{Conclusions}

We have developed a simulation of tropospheric bromine coupled to oxidant-aerosol chemistry in the GEOS-Chem global chemical transport model (CTM). Our goal was to better understand the effect of bromine chemistry on tropospheric ozone and mercury, for both the present and preindustrial atmospheres.

We found that standard gas-phase mechanisms for bromine chemistry are unable to reproduce observed levels of tropospheric $\mathrm{BrO}$, including the latitudinal and seasonal variations reported in the new GOME-2 satellite product of Theys et al. (2011). Considerable improvement is achieved by including in GEOS-Chem the $\mathrm{HOBr}+\mathrm{HBr}$ reaction in aerosols. This brings model $\mathrm{BrO}$ into the observed range and reproduces major features of the satellite observations including the increase with latitude and the seasonal maxima in northern mid-latitudes in winter and in the Arctic in spring. Laboratory studies provide ample evidence for the $\mathrm{HOBr}+\mathrm{HBr}$ reaction but offer limited quantitative informa- tion to constrain models. The reactive uptake probability approach used here $(\gamma=0.2$ for sulfate and sea-salt aerosols, $\gamma=0.1$ for ice crystals) is probably too simplistic. There is a need to better characterize this reaction over a range of aerosol types and temperatures relevant to the troposphere.

Tropospheric bromine chemistry in GEOS-Chem decreases the present-day global burden of tropospheric ozone by $6.5 \%$. This is due in part to loss of $\mathrm{NO}_{\mathrm{x}}$ by $\mathrm{BrNO}_{3}$ formation and hydrolysis, and in part to catalytic loss of ozone by $\mathrm{HOBr}$ formation and photolysis. Ozone mixing ratios decrease by $<1-8 \mathrm{nmol} \mathrm{mol}^{-1}$ depending on region and season, with the largest effects in the extratropical Northern Hemisphere in spring. The global mean $\mathrm{OH}$ concentration decreases by $4 \%$. These changes in ozone and $\mathrm{OH}$ appear to ameliorate previous GEOS-Chem biases in comparisons to observations, although more work is needed to evaluate the simulation of ozone.

We find that bromine chemistry significantly improves the ability of global models to reproduce surface ozone observations from the turn of the 20th century. BrO concentrations in GEOS-Chem are comparable in the present-day and pre-industrial atmospheres, as the effect of decreased methane (suppressing the $\mathrm{BrO}_{\mathrm{x}}$ sink from the $\mathrm{CH}_{2} \mathrm{O}+\mathrm{Br}$ reaction) is compensated by the effect of decreased aerosol (suppressing the $\mathrm{BrO}_{\mathrm{x}}$ source from the $\mathrm{HBr}+\mathrm{HOBr}$ reaction). Comparison of pre-industrial simulations with the GEOS-Chem and p-TOMCAT CTMs to 1876-1886 observations at Montsouris (France) show mean overestimates of $6 \mathrm{nmol} \mathrm{mol}^{-1}$ in GEOS-Chem and $3 \mathrm{nmol} \mathrm{mol}^{-1}$ in $\mathrm{p}$ TOMCAT without bromine chemistry. Including bromine chemistry has similar effects in both models, fully correcting the bias relative to observations in p-TOMCAT and reducing it by half in GEOS-Chem. It suppresses the winter-spring model maximum, better representing the aseasonal behavior of the observations. Bromine chemistry in GEOS-Chem decreases the natural surface ozone background over the US by $3 \mathrm{nmol} \mathrm{mol}^{-1}$ on an annual mean basis, a significant increment when assessing the effect of anthropogenic emissions on ozone exposure. Because the effect of bromine chemistry on ozone is similar in the present-day and pre-industrial atmospheres, we find that the global radiative forcing from anthropogenic tropospheric ozone is negligibly affected. However, the impact on radiative forcing may be sensitive to changes in sea salt debromination and assumptions about heterogeneous chemistry that require further investigation.

In contrast to the similarity between $\mathrm{BrO}$ concentrations in the pre-industrial troposphere and present-day, we find that $\mathrm{Br}$ atom concentrations are $40 \%$ higher (global mean) in the pre-industrial troposphere because of lower ozone. It has been hypothesized that $\mathrm{Br}$ could provide the main atmospheric oxidant for conversion of elemental mercury $\mathrm{Hg}(0)$ to $\mathrm{Hg}(\mathrm{II})$, with a linear-to-quadratic dependence on Br concentrations (Holmes et al., 2006, 2010). If so, anthropogenic ozone would have an important impact on the atmospheric lifetime of mercury. Based on best estimates for 
$\mathrm{Hg}-\mathrm{Br}$ kinetics, we find in GEOS-Chem that the lifetime of $\mathrm{Hg}(0)$ against oxidation to $\mathrm{Hg}(\mathrm{II})$ by $\mathrm{Br}$ atoms was 4 months in the pre-industrial atmosphere as compared to 7 months at present. Most of the anthropogenic increase in tropospheric ozone has taken place since 1950, and background surface ozone concentrations at northern mid-latitudes have continued to increase in recent decades. Thus historical mercury emissions from human activity (mining, industry, combustion) may not have dispersed globally to the extent previously thought, but instead deposited mostly to the northern mid-latitudes. This could possibly explain observations of elevated mercury in North Atlantic subsurface waters (Soerensen et al., 2010) and the recent trend of decreasing atmospheric concentrations over the North Atlantic (Slemr et al., 2011). It should be emphasized, however, that the role of $\mathrm{Br}$ as a global mercury oxidant remains hypothetical. Our results stress the need for further research to better establish this role.

Acknowledgements. This work was funded by the NASA Atmospheric Composition Modeling and Analysis Program and by the Atmospheric Chemistry Program of the National Science Foundation. J.A.P. and X.Y. thank NERC and NCAS for funding. The authors would like to thank P. Pongprueksa for his helpful comment on updated mercury kinetics. The authors would also like to thank R. von Glasow and an anonymous reviewer for their helpful comments and suggestions.

Edited by: R. Sander

\section{References}

Abbatt, J. P. D.: Heterogeneous reaction of $\mathrm{HOBr}$ with $\mathrm{HBr}$ and $\mathrm{HCl}$ on ice surfaces at $228 \mathrm{~K}$, Geophys. Res. Lett., 21, 665-668, doi:10.1029/94gl00775, 1994.

Abbatt, J. P. D.: Interactions of $\mathrm{HBr}, \mathrm{HCl}$, and $\mathrm{HOBr}$ with supercooled sulfuric acid solutions of stratospheric composition, J. Geophys. Res., 100, 14009-14017, doi:10.1029/95jd01367, 1995.

Abbatt, J. P. D. and Waschewsky, G. C. G.: Heterogeneous Interactions of $\mathrm{HOBr}, \mathrm{HNO}_{3}, \mathrm{O}_{3}$, and $\mathrm{NO}_{2}$ with Deliquescent $\mathrm{NaCl}$ Aerosols at Room Temperature, J. Phys. Chem. A, 102, 37193725, doi:10.1021/jp980932d, 1998.

Alexander, B., Park, R. J., Jacob, D. J., Li, Q. B., Yantosca, R. M., Savarino, J., Lee, C. C. W., and Thiemens, M. H.: Sulfate formation in sea-salt aerosols: Constraints from oxygen isotopes, J. Geophys. Res., 110, D10307, doi:10.1029/2004jd005659, 2005.

Arnaud, P.: Cours de chimie organique, 3 Edn., Gauthier-Villars, Paris, 1966.

Atkinson, R., Baulch, D. L., Cox, R. A., Hampson, R. F., Rossi, M. J., and Troe, J.: Evaluated Kinetic and Photochemical Data for Atmospheric Chemistry: Supplement VIII, J. Phys. Chem. Ref. Data, 29, 167-266, 2000a.

Atkinson, R., Baulch, D. L., Cox, R. A., Hampson, R. F., Rossi, M. J., and Troe, J.: Evaluated Kinetic and Photochemical Data for Atmospheric Chemistry. Supplement IX, Heterogeneous Chem- istry, non-reactive uptake, http://www.iupac-kinetic.ch.cam.ac. uk/, 2000b.

Balkanski, Y. J., Jacob, D. J., Gardner, G. M., Graustein, W. C., and Turekian, K. K.: Transport and Residence Times of Tropospheric Aerosols Inferred from a Global Three-Dimensional Simulation of ${ }^{210} \mathrm{~Pb}$, J. Geophys. Res., 98, 20573-20586, doi:10.1029/93jd02456, 1993.

Beckwith, R. C., Wang, T. X., and Margerum, D. W.: Equilibrium and Kinetics of Bromine Hydrolysis, Inorg. Chem., 35, 9951000, doi:10.1021/ic950909w, 1996.

Bergan, T., Gallardo, L., and Rodhe, H.: Mercury in the global troposphere: a three-dimensional model study, Atmos. Environ., 33, 1575-1585, 1999.

Bey, I., Jacob, D. J., Yantosca, R. M., Logan, J. A., Field, B. D., Fiore, A. M., Li, Q., Liu, H. Y., Mickley, L. J., and Schultz, M. G.: Global modeling of tropospheric chemistry with assimilated meteorology: Model description and evaluation, J. Geophys. Res., 106, 23073-23095, 2001.

Butler, J. H., King, D. B., Lobert, J. M., Montzka, S. A., YvonLewis, S. A., Hall, B. D., Warwick, N. J., Mondeel, D. J., Aydin, M., and Elkins, J. W.: Oceanic distributions and emissions of short-lived halocarbons, Global Biogeochem. Cy., 21, GB1023, doi:10.1029/2006gb002732, 2007.

Calvert, J. G. and Lindberg, S. E.: Mechanisms of mercury removal by $\mathrm{O}_{3}$ and $\mathrm{OH}$ in the atmosphere, Atmos. Environ., 39, 33553367, 2005.

Carpenter, L. J., Sturges, W. T., Penkett, S. A., Liss, P. S., Alicke, B., Hebestreit, K., and Platt, U.: Short-lived alkyl iodides and bromides at Mace Head, Ireland: Links to biogenic sources and halogen oxide production, J. Geophys. Res., 104, 1679-1689, 1999.

Chaix, L., Allanic, A., and Rossi, M. J.: Heterogeneous Chemistry of $\mathrm{HOBr}$ on Different Types of Ice and on Ice Doped with $\mathrm{HCl}$, $\mathrm{HBr}$, and $\mathrm{HNO}_{3}$ at $175 \mathrm{~K}<\mathrm{T}<215 \mathrm{~K}$, J. Phys. Chem. A, 104, 7268-7277, doi:10.1021/jp001018z, 2000.

Clerbaux, C., Cunnold, D. M. (Coordinating Lead Authors), Anderson, J., Engel, A., Fraser, P. J., Mahieu, E., Manning, A., Miller, J., Montzka, S. A., Nassar, R., Prinn, R., Reimann, S., Rinsland, C. P., Simmonds, P., Verdonik, D., Weiss, R., Wuebbles, D., and Yokouchi, Y.: Long-lived compounds, Chapter 1 in Scientific Assessment of Ozone Depletion: 2006, Global Ozone Research and Monitoring Project-Report No. 50, World Meteorological Organization, Geneva, Switzerland, 2007.

Crutzen, P. J. and Schmailzl, U.: Chemical budgets of the stratosphere, Planet. Space Sci., 31, 1009-1032, 1983.

Dean, J. A.: Lange's Handbook of Chemistry, McGraw-Hill, Inc., 1992.

Dentener, F., Keating, T., and Akimoto, H. (Eds.): Part A in Hemispheric Transport of Air Pollution, Ozone and Particulate Matter, United Nations Economic Commission for Europe, New York, 2010.

Derwent, R. G., Simmonds, P. G., Manning, A. J., and Spain, T. G.: Trends over a 20-year period from 1987 to 2007 in surface ozone at the atmospheric research station, Mace Head, Ireland, Atmos. Environ., 41, 9091-9098, 2007.

Donohoue, D. L., Bauer, D., Cossairt, B., and Hynes, A. J.: Temperature and Pressure Dependent Rate Coefficients for the Reaction of $\mathrm{Hg}$ with $\mathrm{Br}$ and the Reaction of $\mathrm{Br}$ with $\mathrm{Br}$ : A Pulsed Laser Photolysis-Pulsed Laser Induced Fluorescence Study, J. Phys. 
Chem. A, 110, 6623-6632, doi:10.1021/jp054688j, 2006.

Fickert, S., Adams, J. W., and Crowley, J. N.: Activation of $\mathrm{Br}_{2}$ and $\mathrm{BrCl}$ via uptake of $\mathrm{HOBr}$ onto aqueous salt solutions, J. Geophys. Res., 104, 23719-23727, doi:10.1029/1999jd900359, 1999.

Fischer, E. V., Jacob, D. J., Millet, D. B., Yantosca, R. M., and Mao, J.: The role of the ocean in the global atmospheric budget of acetone, Geophys. Res. Lett., 39, L01807, doi:10.1029/2011g1050086, 2012.

Fisher, J. A., Jacob, D. J., Purdy, M. T., Kopacz, M., Le Sager, P., Carouge, C., Holmes, C. D., Yantosca, R. M., Batchelor, R. L., Strong, K., Diskin, G. S., Fuelberg, H. E., Holloway, J. S., Hyer, E. J., McMillan, W. W., Warner, J., Streets, D. G., Zhang, Q., Wang, Y., and $\mathrm{Wu}, \mathrm{S}$.: Source attribution and interannual variability of Arctic pollution in spring constrained by aircraft (ARCTAS, ARCPAC) and satellite (AIRS) observations of carbon monoxide, Atmos. Chem. Phys., 10, 977-996, doi:10.5194/acp10-977-2010, 2010.

Fitzenberger, R., Bösch, H., Camy-Peyret, C., Chipperfield, M. P., Harder, H., Platt, U., Sinnhuber, B., M, Wagner, T., and Pfeilsticker, K.: First profile measurements of tropospheric BrO, Geophys. Res. Lett., 27, 2921-2924, doi:10.1029/2000gl011531, 2000.

Frenzel, A., Scheer, V., Sikorski, R., George, C., Behnke, W., and Zetzsch, C.: Heterogeneous Interconversion Reactions of $\mathrm{BrNO}_{2}, \mathrm{ClNO}_{2}, \mathrm{Br}_{2}$, and $\mathrm{Cl}_{2}$, J. Phys. Chem. A, 102, 13291337, doi:10.1021/jp973044b, 1998.

Frieß, U., Chipperfield, M. P., Harder, H., Otten, C., Platt, U., Pyle, J., Wagner, T., and Pfeilsticker, K.: Intercomparison of measured and modelled BrO slant column amounts for the Arctic winter and spring 1994/95, Geophys. Res. Lett., 26, 1861-1864, doi:10.1029/1999g1900345, 1999.

Fu, T.-M., Jacob, D. J., Wittrock, F., Burrows, J. P., Vrekoussis, M., and Henze, D. K.: Global budgets of atmospheric glyoxal and methylglyoxal, and implications for formation of secondary organic aerosols, J. Geophys. Res., 113, D15303, doi:10.1029/2007jd009505, 2008.

Goodsite, M. E., Plane, J. M. C., and Skov, H.: A Theoretical Study of the Oxidation of $\mathrm{Hg}^{0}$ to $\mathrm{HgBr}_{2}$ in the Troposphere, Environ. Sci. Technol., 38, 1772-1776, doi:10.1021/es034680s, 2004.

Haag, W. R. and Hoigne, J.: Ozonation of bromide-containing waters: kinetics of formation of hypobromous acid and bromate, Environ. Sci. Technol., 17, 261-267, doi:10.1021/es00111a004, 1983.

Harder, H., Camy, Peyret, C., Ferlemann, F., Fitzenberger, R., Hawat, T., Osterkamp, H., Schneider, M., Perner, D., Platt, U., Vradelis, P., and Pfeilsticker, K.: Stratospheric BrO profiles measured at different latitudes and seasons: Atmospheric observations, Geophys. Res. Lett., 25, 3843-3846, doi:10.1029/1998g1900026, 1998.

Hendrick, F., Van Roozendael, M., Chipperfield, M. P., Dorf, M., Goutail, F., Yang, X., Fayt, C., Hermans, C., Pfeilsticker, K., Pommereau, J.-P., Pyle, J. A., Theys, N., and De Mazière, M.: Retrieval of stratospheric and tropospheric BrO profiles and columns using ground-based zenith-sky DOAS observations at Harestua, $60^{\circ} \mathrm{N}$, Atmos. Chem. Phys., 7, 4869-4885, doi:10.5194/acp-7-4869-2007, 2007.

Holmes, C. D., Jacob, D. J., and Yang, X.: Global lifetime of elemental mercury against oxidation by atomic bromine in the free troposphere, Geophys. Res. Lett., 33, L20808, doi:10.1029/2006g1027176, 2006.

Holmes, C. D., Jacob, D. J., Mason, R. P., and Jaffe, D. A.: Sources and deposition of reactive gaseous mercury in the marine atmosphere, Atmos. Environ., 43, 2278-2285, 2009.

Holmes, C. D., Jacob, D. J., Corbitt, E. S., Mao, J., Yang, X., Talbot, R., and Slemr, F.: Global atmospheric model for mercury including oxidation by bromine atoms, Atmos. Chem. Phys., 10, 12037-12057, doi:10.5194/acp-10-12037-2010, 2010.

Horowitz, L. W.: Past, present, and future concentrations of tropospheric ozone and aerosols: Methodology, ozone evaluation, and sensitivity to aerosol wet removal, J. Geophys. Res., 111, D22211, doi:10.1029/2005JD006937, 2006.

Hossaini, R., Chipperfield, M. P., Monge-Sanz, B. M., Richards, N. A. D., Atlas, E., and Blake, D. R.: Bromoform and dibromomethane in the tropics: a 3-D model study of chemistry and transport, Atmos. Chem. Phys., 10, 719-735, doi:10.5194/acp10-719-2010, 2010.

Hynes, A. J., Donohoue, D. L., Goodsite, M. E., Hedgecock, I. M., Pirrone, N., and Mason, R.: Our current understanding of major chemical and physical processes affecting mercury dynamics in the atmosphere and at the air-water/terrestrial interfaces, in: Mercury Fate and Transport in the Global Atmosphere, edited by: Pirrone, N. and Mason, R. P., Springer, chap. 14, 427-457, 2009.

Jacob, D. J.: Heterogeneous chemistry and tropospheric ozone, Atmos. Environ., 34, 2131-2159, 2000.

Jacobson, M. Z. and Turco, R. P.: SMVGEAR: A sparse-matrix, vectorized gear code for atmospheric models, Atmos. Environ., 28, 273-284, 1994.

Kerkweg, A., Jöckel, P., Warwick, N., Gebhardt, S., Brenninkmeijer, C. A. M., and Lelieveld, J.: Consistent simulation of bromine chemistry from the marine boundary layer to the stratosphere - Part 2: Bromocarbons, Atmos. Chem. Phys., 8, 5919-5939, doi:10.5194/acp-8-5919-2008, 2008.

Kiehl, J. T., Schneider, T. L., Portmann, R. W., and Solomon, S.: Climate forcing due to tropospheric and stratospheric ozone, J. Geophys. Res., 104, 31239-31254, doi:10.1029/1999jd900991, 1999.

King, K. D., Golden, D. M., and Benson, S. W.: Kinetics of the gas-phase thermal bromination of acetone. Heat of formation and stabilization energy of the acetonyl radical, J. Am. Chem. Soc., 92, 5541-5546, doi:10.1021/ja00722a001, 1970.

Lamarque, J.-F., Hess, P., Emmons, L., Buja, L., Washington, W., and Granier, C.: Tropospheric ozone evolution between 1890 and 1990, J. Geophys. Res., 110, D08304, doi:10.1029/2004JD005537, 2005.

Lary, D. J.: Halogens and the chemistry of the free troposphere, Atmos. Chem. Phys., 5, 227-237, doi:10.5194/acp-5-227-2005, 2005.

Law, K. S., Sturges, W. T. (Coordinating Lead Authors), Blake, D. R., Blake, N. J., Burkholder, J. B., Butler, J. H., Cox, R. A., Haynes, P. H., Ko, M. K. W., Kreher, K., Mari, C., Pfeilsticker, K., Plane, J. M. C., Salawitch, R. J., Schiller, C., Sinnhuber, B.M., von Glasow, R., Warwick, N. J., Wuebbles, D. J., and YvonLewis, S. A.: Halogenated Very Short-Lived Substances, Chapter 2 in Scientific Assessment of Ozone Depletion: 2006, Global Ozone Research and Monitoring Project-Report No. 50, World Meteorological Organization, Geneva, Switzerland, 2007. 
Lawrence, M. G. and Crutzen, P. J.: The impact of cloud particle gravitational settling on soluble trace gas distributions, Tellus B, 50, 263-289, 1998.

Lelieveld, J., van Aardenne, J., Fischer, H., de Reus, M., Williams, J., and Winkler, P.: Increasing Ozone over the Atlantic Ocean, Science, 304, 1483-1487, doi:10.1126/science.1096777, 2004.

Lewis, E. R. and Schwartz, S. E.: Sea Salt Aerosol Production: Mechanisms, Methods, Measurements and Models - A Critical Review, Geophysical Monograph 152, AGU, Washington, DC, 2004.

Liang, Q., Stolarski, R. S., Kawa, S. R., Nielsen, J. E., Douglass, A. R., Rodriguez, J. M., Blake, D. R., Atlas, E. L., and Ott, L. E.: Finding the missing stratospheric Bry: a global modeling study of $\mathrm{CHBr}_{3}$ and $\mathrm{CH}_{2} \mathrm{Br}_{2}$, Atmos. Chem. Phys., 10, 2269-2286, doi:10.5194/acp-10-2269-2010, 2010.

Lin, J.-T., McElroy, M. B., and Boersma, K. F.: Constraint of anthropogenic $\mathrm{NO}_{\mathrm{x}}$ emissions in China from different sectors: a new methodology using multiple satellite retrievals, Atmos. Chem. Phys., 10, 63-78, doi:10.5194/acp-10-63-2010, 2010.

Lindberg, S., Bullock, R., Ebinghaus, R., Engstrom, D., Feng, X., Fitzgerald, W., Pirrone, N., Prestbo, E., and Seigneur, C.: A Synthesis of Progress and Uncertainties in Attributing the Sources of Mercury in Deposition, AMBIO, 36, 19-33, 2007.

Liu, H., Jacob, D. J., Bey, I., and Yantosca, R. M.: Constraints from ${ }^{210} \mathrm{~Pb}$ and ${ }^{7} \mathrm{Be}$ on wet deposition and transport in a global three-dimensional chemical tracer model driven by assimilated meteorological fields, J. Geophys. Res., 106, 1210912128, doi:10.1029/2000jd900839, 2001.

Logan, J. A., Staehelin, J., Megretskaia, I. A., Cammas, J.-P., Thouret, V., Claude, H., De Backer, H., Steinbacher, M., Scheel, H. E., Stubi, R., Frohlich, M., and Derwent, R. G.: Changes in ozone over Europe since 1990: analysis of ozone measurements from sondes regular aircraft (MOZAIC) and alpine surface sites, J. Geophys. Res., 117, D09301, doi:10.1029/2011JD016952, 2012.

Mao, J., Jacob, D. J., Evans, M. J., Olson, J. R., Ren, X., Brune, W. H., Clair, J. M. St., Crounse, J. D., Spencer, K. M., Beaver, M. R., Wennberg, P. O., Cubison, M. J., Jimenez, J. L., Fried, A., Weibring, P., Walega, J. G., Hall, S. R., Weinheimer, A. J., Cohen, R. C., Chen, G., Crawford, J. H., McNaughton, C., Clarke, A. D., Jaeglé, L., Fisher, J. A., Yantosca, R. M., Le Sager, P., and Carouge, $\mathrm{C} .:$ Chemistry of hydrogen oxide radicals $\left(\mathrm{HO}_{\mathrm{X}}\right)$ in the Arctic troposphere in spring, Atmos. Chem. Phys., 10, 58235838, doi:10.5194/acp-10-5823-2010, 2010.

Mao, J., Fan, S.-M., and Jacob, D. J.: Radical loss in the atmosphere from $\mathrm{Cu}-\mathrm{Fe}$ redox coupling in aerosol, Nature, submitted, 2012.

Marenco, A., Gouget, H., Nédélec, P., Pagés, J.-P., and Karcher, F.: Evidence of a long-term increase in tropospheric ozone from Pic du Midi data series: Consequences: Positive radiative forcing, J. Geophys. Res., 99, 16617-16632, 1994.

Martin, R. V., Jacob, D. J., Logan, J. A., Bey, I., Yantosca, R. M., Staudt, A. C., Li, Q., Fiore, A. M., Duncan, B. N., Liu, H., Ginoux, P., and Thouret, V.: Interpretation of TOMS observations of tropical tropospheric ozone with a global model and in situ observations, J. Geophys. Res., 107, 4351, doi:10.1029/2001jd001480, 2002.

McGrath, M. P. and Rowland, F. S.: Ideal Gas Thermodynamic Properties of HOBr, J. Phys. Chem., 98, 4773-4775, doi:10.1021/j100069a001, 1994.
McLinden, C. A., Olsen, S. C., Hannegan, B., Wild, O., Prather, M. J., and Sundet, J.: Stratospheric ozone in 3-D models: A simple chemistry and the cross-tropopause flux, J. Geophys. Res., 105, 14653-14665, 2000.

Mickley, L. J., Murti, P. P., Jacob, D. J., Logan, J. A., Koch, D. M., and Rind, D.: Radiative forcing from tropospheric ozone calculated with a unified chemistry-climate model, J. Geophys. Res., 104, 30153-30172, doi:10.1029/1999jd900439, 1999.

Mickley, L. J., Jacob, D. J., and Rind, D.: Uncertainty in preindustrial abundance of tropospheric ozone: Implications for radiative forcing calculations, J. Geophys. Res., 106, 3389-3399, doi:10.1029/2000jd900594, 2001.

Mochida, M., Akimoto, H., van den Bergh, H., and Rossi, M. J.: Heterogeneous Kinetics of the Uptake of $\mathrm{HOBr}$ on Solid Alkali Metal Halides at Ambient Temperature, J. Phys. Chem. A, 102, 4819-4828, doi:10.1021/jp980849q, 1998.

Monks, P. S.: A review of the observations and origins of the spring ozone maximum, Atmos. Environ., 34, 3545-3561, 2000.

Montzka, S. A., Butler, J. H., Hall, B. D., Mondeel, D. J., and Elkins, J. W.: A decline in tropospheric organic bromine, Geophys. Res. Lett., 30, 1826, doi:10.1029/2003GL017745, 2003.

Montzka, S. A., Reimann, S. (Coordinating Lead Authors), Engel, A., Krüger, K., O’Doherty, S., Sturges, W. T., Blake, D. R., Dorf, M., Fraser, P., Froidevaux, L., Jucks, K. W., Kreher, K., Kurylo, M. J., Mellouki, A., Miller, J., Nielsen, O.-J., Orkin, V. L., Prinn, R. G., Rhew, R., Santee, M. L., Stohl, A., and Verdonik, D.: Ozone-Depleting Substances (OESs) and Related Chemicals, Chapter 1 in Scientific Assessment of Ozone Depletion: 2010, Global Ozone Research and Monitoring Project-Report No. 52, 516 pp., World Meteorological Organization, Geneva, Switzerland, 2011.

Nassar, R., Logan, J. A., Megretskaia, I. A., Murray, L. T., Zhang, L., and Jones, D. B. A.: Analysis of tropical tropospheric ozone, carbon monoxide, and water vapor during the 2006 El Niño using TES observations and the GEOS-Chem model, J. Geophys. Res., 114, D17304, doi:10.1029/2009JD011760, 2009.

Neuman, J. A., Nowak, J. B., Huey, L. G., Burkholder, J. B., Dibb, J. E., Holloway, J. S., Liao, J., Peischl, J., Roberts, J. M., Ryerson, T. B., Scheuer, E., Stark, H., Stickel, R. E., Tanner, D. J., and Weinheimer, A.: Bromine measurements in ozone depleted air over the Arctic Ocean, Atmos. Chem. Phys., 10, 6503-6514, doi:10.5194/acp-10-6503-2010, 2010.

Oltmans, S. J., Lefohn, A. S., Harris, J. M., Galbally, I., Scheel, H. E., Bodeker, G., Brunke, E., Claude, H., Tarasick, D., Johnson, B. J., Simmonds, P., Shadwick, D., Anlauf, K., Hayden, K., Schmidlin, F., Fujimoto, T., Akagi, K., Meyer, C., Nichol, S., Davies, J., Redondas, A., and Cuevas, E.: Long-term changes in tropospheric ozone, Atmos. Environ., 40, 3156-3173, 2006.

Orlando, J. J. and Tyndall, G. S.: Rate Coefficients for the Thermal Decomposition of $\mathrm{BrONO}_{2}$ and the Heat of Formation of $\mathrm{BrONO}_{2}$, J. Phys. Chem., 100, 19398-19405, doi:10.1021/jp9620274, 1996.

Park, R. J., Jacob, D. J., Field, B. D., Yantosca, R. M., and Chin, M.: Natural and transboundary pollution influences on sulfate-nitrate-ammonium aerosols in the United States: Implications for policy, J. Geophys. Res., 109, D15204, doi:10.1029/2003jd004473, 2004.

Parrish, D. D., Millet, D. B., and Goldstein, A. H.: Increasing ozone in marine boundary layer inflow at the west coasts of 
North America and Europe, Atmos. Chem. Phys., 9, 1303-1323, doi:10.5194/acp-9-1303-2009, 2009.

Paulot, F., Crounse, J. D., Kjaergaard, H. G., Kürten, A., St. Clair, J. M., Seinfeld, J. H., and Wennberg, P. O.: Unexpected Epoxide Formation in the Gas-Phase Photooxidation of Isoprene, Science, 325, 730-733, 2009a.

Paulot, F., Crounse, J. D., Kjaergaard, H. G., Kroll, J. H., Seinfeld, J. H., and Wennberg, P. O.: Isoprene photooxidation: new insights into the production of acids and organic nitrates, Atmos. Chem. Phys., 9, 1479-1501, doi:10.5194/acp-9-1479-2009, 2009b.

Platt, U. and Hönninger, G.: The role of halogen species in the troposphere, Chemosphere, 52, 325-338, 2003.

Prinn, R. G., Huang, J., Weiss, R. F., Cunnold, D. M., Fraser, P. J., Simmonds, P. G., McCulloch, A., Harth, C., Reimann, S., Salameh, P., O’Doherty, S., Wang, R. H. J., Porter, L. W., Miller, B. R., and Krummel, P. B.: Evidence for variability of atmospheric hydroxyl radicals over the past quarter century, Geophys. Res. Lett., 32, L07809, doi:10.1029/2004g1022228, 2005.

Pyle, D. M. and Mather, T. A.: Halogens in igneous processes and their fluxes to the atmosphere and oceans from volcanic activity: A review, Chem. Geol., 263, 110-121, 2009.

Pyle, J. A., Ashfold, M. J., Harris, N. R. P., Robinson, A. D., Warwick, N. J., Carver, G. D., Gostlow, B., O’Brien, L. M., Manning, A. J., Phang, S. M., Yong, S. E., Leong, K. P., Ung, E. H., and Ong, S.: Bromoform in the tropical boundary layer of the Maritime Continent during OP3, Atmos. Chem. Phys., 11, 529-542, doi:10.5194/acp-11-529-2011, 2011.

Quack, B. and Wallace, D. W. R.: Air-sea flux of bromoform: Controls, rates, and implications, Global Biogeochem. Cy., 17, GB1004, doi:10.1029/2003GB002187, 2003.

Richter, A., Wittrock, F., Ladstätter-Weißenmayer, A., and Burrows, J. P.: GOME measurements of stratospheric and tropospheric BrO, Adv. Space Res., 29, 1667-1672, 2002.

Saiz-Lopez, A., Lamarque, J.-F., Kinnison, D. E., Tilmes, S., Ordóñez, C., Orlando, J. J., Conley, A. J., Plane, J. M. C., Mahajan, A. S., Sousa Santos, G., Atlas, E. L., Blake, D. R., Sander, S. P., Schauffler, S., Thompson, A. M., and Brasseur, G.: Estimating the climate significance of halogen-driven ozone loss in the tropical marine troposphere, Atmos. Chem. Phys., 12, 3939-3949, doi:10.5194/acp-12-3939-2012, 2012.

Salawitch, R. J., Canty, T., Kurosu, T., Chance, K., Liang, Q., da Silva, A., Pawson, S., Nielsen, J. E., Rodriguez, J. M., Bhartia, P. K., Liu, X., Huey, L. G., Liao, J., Stickel, R. E., Tanner, D. J., Dibb, J. E., Simpson, W. R., Donohoue, D., Weinheimer, A., Flocke, F., Knapp, D., Montzka, D., Neuman, J. A., Nowak, J. B., Ryerson, T. B., Oltmans, S., Blake, D. R., Atlas, E. L., Kinnison, D. E., Tilmes, S., Pan, L. L., Hendrick, F., Van Roozendael, M., Kreher, K., Johnston, P. V., Gao, R. S., Johnson, B., Bui, T. P., Chen, G., Pierce, R. B., Crawford, J. H., and Jacob, D. J.: A new interpretation of total column BrO during Arctic spring, Geophys. Res. Lett., 37, L21805, doi:10.1029/2010g1043798, 2010.

Saltzman, E. S., Aydin, M., De Bruyn, W. J., King, D. B., and Yvon-Lewis, S. A.: Methyl bromide in preindustrial air: Measurements from an Antarctic ice core, J. Geophys. Res., 109, D05301, doi:10.1029/2003JD004157, 2004.

Sander, R.: Compilation of Henry's Law Constants for Inorganic and Organic Species of Potential Importance in Environmental Chemistry, http://www.henrys-law.org, 1999.
Sander, R., Rudich, Y., von Glasow, R., and Crutzen, P. J.: The role of $\mathrm{BrNO}_{3}$ in marine tropospheric chemistry: A model study, Geophys. Res. Lett., 26, 2857-2860, 1999.

Sander, R., Keene, W. C., Pszenny, A. A. P., Arimoto, R., Ayers, G. P., Baboukas, E., Cainey, J. M., Crutzen, P. J., Duce, R. A., Hönninger, G., Huebert, B. J., Maenhaut, W., Mihalopoulos, N., Turekian, V. C., and Van Dingenen, R.: Inorganic bromine in the marine boundary layer: a critical review, Atmos. Chem. Phys., 3, 1301-1336, doi:10.5194/acp-3-1301-2003, 2003.

Sander, S. P., Friedl, R. R., Abbatt, J. P. D., Barker, J. R., Burkholder, J. B., Golden, D. M., Kolb, C. E., Kurylo, M. J., Moortgat, G. K., Wine, P. H., Huie, R. E., and Orkin, V. L.: Chemical kinetics and photochemical data for use in atmospheric studies, Evaluation Number 17, NASA Jet Propulsion Laboratory, 2011.

Sauvage, B., Martin, R. V., van Donkelaar, A., Liu, X., Chance, K., Jaeglé, L., Palmer, P. I., Wu, S., and Fu, T.-M.: Remote sensed and in situ constraints on processes affecting tropical tropospheric ozone, Atmos. Chem. Phys., 7, 815-838, doi:10.5194/acp-7-815-2007, 2007.

Scheffler, D., Grothe, H., Willner, H., Frenzel, A., and Zetzsch, C.: Properties of Pure Nitryl Bromide. Thermal Behavior, UV/Vis and FTIR Spectra, and Photoisomerization to trans-BrONO in an Argon Matrix, Inorg. Chem., 36, 335-338, doi:10.1021/ic9606946, 1997.

Schwartz, S. E.: Mass-transport considerations pertinent to aqueous-phase reactions of gases in liquid-water clouds, in: Chemistry of Multiphase Atmospheric Systems, edited by: Jaechske, W., Springer, Heidelberg, 415-471, 1986.

Schweitzer, F., Mirabel, P., and George, C.: Uptake of Hydrogen Halides by Water Droplets, J. Phys. Chem. A, 104, 72-76, doi:10.1021/jp992621o, 2000.

Seakins, P. W., Pilling, M. J., Niiranen, J. T., Gutman, D., and Krasnoperov, L. N.: Kinetics and thermochemistry of $\mathrm{R}+\mathrm{HBr}$ $\leftrightarrow \mathrm{RH}+\mathrm{Br}$ reactions: Determinations of the heat of formation of $\mathrm{C}_{2} \mathrm{H}_{5}, /-\mathrm{C}_{3} \mathrm{H}_{7}$, sec- $\mathrm{C}_{4} \mathrm{H}_{9}$, and $t-\mathrm{C}_{4} \mathrm{H}_{9}$ radicals, J. Phys. Chem., 96, 9847-9855, doi:10.1021/j100203a050, 1992.

Selin, N. E., Jacob, D. J., Yantosca, R. M., Strode, S., Jaeglé, L., and Sunderland, E. M.: Global 3-D land-ocean-atmosphere model for mercury: Present-day versus preindustrial cycles and anthropogenic enrichment factors for deposition, Global Biogeochem. Cy., 22, GB2011, doi:10.1029/2007gb003040, 2008.

Shindell, D. T., Faluvegi, G., and Bell, N.: Preindustrial-to-presentday radiative forcing by tropospheric ozone from improved simulations with the GISS chemistry-climate GCM, Atmos. Chem. Phys., 3, 1675-1702, doi:10.5194/acp-3-1675-2003, 2003.

Simpson, W. R., von Glasow, R., Riedel, K., Anderson, P., Ariya, P., Bottenheim, J., Burrows, J., Carpenter, L. J., Frieß, U., Goodsite, M. E., Heard, D., Hutterli, M., Jacobi, H.-W., Kaleschke, L., Neff, B., Plane, J., Platt, U., Richter, A., Roscoe, H., Sander, R., Shepson, P., Sodeau, J., Steffen, A., Wagner, T., and Wolff, E.: Halogens and their role in polar boundary-layer ozone depletion, Atmos. Chem. Phys., 7, 4375-4418, doi:10.5194/acp-74375-2007, 2007.

Slemr, F., Seiler, W., and Schuster, G.: Latitudinal Distribution of Mercury Over the Atlantic Ocean, J. Geophys. Res., 86, 11591166, doi:10.1029/JC086iC02p01159, 1981.

Slemr, F., Schuster, G., and Seiler, W.: Distribution, speciation, and budget of atmospheric mercury, J. Atmos. Chem., 3, 407-434, 
doi:10.1007/bf00053870, 1985.

Slemr, F., Brunke, E.-G., Ebinghaus, R., and Kuss, J.: Worldwide trend of atmospheric mercury since 1995, Atmos. Chem. Phys., 11, 4779-4787, doi:10.5194/acp-11-4779-2011, 2011.

Soerensen, A. L., Sunderland, E. M., Holmes, C. D., Jacob, D. J., Yantosca, R. M., Skov, H., Christensen, J. H., Strode, S. A., and Mason, R. P.: An Improved Global Model for Air-Sea Exchange of Mercury: High Concentrations over the North Atlantic, Environ. Sci. Technol., 44, 8574-8580, doi:10.1021/es102032g, 2010.

Soerensen, A. L., Jacob, D. J., Streets, D. G., Witt, M., Ebinghaus, R., Mason, R. P., Andersson, M., and Sunderland, E. M.: Multidecadal decline of mercury in the North Atlantic atmosphere explained by changing subsurface seawater concentrations, Geophys. Res. Lett., submitted, 2012.

Spivakovsky, C. M., Logan, J. A., Montzka, S. A., Balkanski, Y. J., Foreman-Fowler, M., Jones, D. B. A., Horowitz, L. W., Fusco, A. C., Brenninkmeijer, C. A. M., Prather, M. J., Wofsy, S. C., and McElroy, M. B.: Three-dimensional climatological distribution of tropospheric $\mathrm{OH}$ : Update and evaluation, J. Geophys. Res., 105, 8931-8980, doi:10.1029/1999jd901006, 2000.

Steffen, A., Douglas, T., Amyot, M., Ariya, P., Aspmo, K., Berg, T., Bottenheim, J., Brooks, S., Cobbett, F., Dastoor, A., Dommergue, A., Ebinghaus, R., Ferrari, C., Gardfeldt, K., Goodsite, M. E., Lean, D., Poulain, A. J., Scherz, C., Skov, H., Sommar, J., and Temme, C.: A synthesis of atmospheric mercury depletion event chemistry in the atmosphere and snow, Atmos. Chem. Phys., 8, 1445-1482, doi:10.5194/acp-8-1445-2008, 2008.

Stone, D. and Evans, M. J.: Impact of halogen chemistry on $\mathrm{HO}_{\mathrm{x}}$ radicals: Comparisons between box and global models with measurements at the Cape Verde Atmospheric Observatory during the Seasonal Oxidant Study, in preparation, 2012.

Streets, D. G., Devane, M. K., Lu, Z., Bond, T. C., Sunderland, E. M., and Jacob, D. J.: All-Time Releases of Mercury to the Atmosphere from Human Activities, Environ. Sci. Technol., 45, 10485-10491, doi:10.1021/es202765m, 2011.

Stuart, A. L. and Jacobson, M. Z.: A timescale investigation of volatile chemical retention during hydrometeor freezing: Nonrime freezing and dry growth riming without spreading, J. Geophys. Res., 108, 4178, doi:10.1029/2001jd001408, 2003.

Stutz, J., Ackermann, R., Fast, J. D., and Barrie, L.: Atmospheric reactive chlorine and bromine at the Great Salt Lake, Utah, Geophys. Res. Lett., 29, 1380, doi:10.1029/2002gl014812, 2002.

Theys, N., Van Roozendael, M., Hendrick, F., Fayt, C., Hermans, C., Baray, J.-L., Goutail, F., Pommereau, J.-P., and De Mazière, M.: Retrieval of stratospheric and tropospheric BrO columns from multi-axis DOAS measurements at Reunion Island $\left(21^{\circ} \mathrm{S}\right.$, $56^{\circ}$ E), Atmos. Chem. Phys., 7, 4733-4749, doi:10.5194/acp-74733-2007, 2007.

Theys, N., Van Roozendael, M., Errera, Q., Hendrick, F., Daerden, F., Chabrillat, S., Dorf, M., Pfeilsticker, K., Rozanov, A., Lotz, W., Burrows, J. P., Lambert, J.-C., Goutail, F., Roscoe, H. K., and De Mazière, M.: A global stratospheric bromine monoxide climatology based on the BASCOE chemical transport model, Atmos. Chem. Phys., 9, 831-848, doi:10.5194/acp-9-831-2009, 2009.

Theys, N., Van Roozendael, M., Hendrick, F., Yang, X., De Smedt, I., Richter, A., Begoin, M., Errera, Q., Johnston, P. V., Kreher, K., and De Mazière, M.: Global observations of tropospheric BrO columns using GOME-2 satellite data, Atmos. Chem. Phys., 11, 1791-1811, doi:10.5194/acp-11-1791-2011, 2011.

US Environmental Protection Agency: Air Quality Criteria for Ozone and Related Photochemical Oxidants (Final), Vols. I, II, and III, 600/R-605/004aF-cF, 2006.

Van Roozendael, M., Wagner, T., Richter, A., Pundt, I., Arlander, D. W., Burrows, J. P., Chipperfield, M., Fayt, C., Johnston, P. V., Lambert, J. C., Kreher, K., Pfeilsticker, K., Platt, U., Pommereau, J. P., Sinnhuber, B. M., Tørnkvist, K. K., and Wittrock, F.: Intercomparison of $\mathrm{BrO}$ measurements from ERS-2 GOME, ground-based and balloon platforms, Adv. Space Res., 29, 16611666, 2002.

Vogt, R., Crutzen, P. J., and Sander, R.: A mechanism for halogen release from sea-salt aerosol in the remote marine boundary layer, Nature, 383, 327-330, 1996.

Volz, A. and Kley, D.: Evaluation of the Montsouris series of ozone measurements made in the nineteenth century, Nature, 332, 240 242, 1988.

von Glasow, R., von Kuhlmann, R., Lawrence, M. G., Platt, U., and Crutzen, P. J.: Impact of reactive bromine chemistry in the troposphere, Atmos. Chem. Phys., 4, 2481-2497, doi:10.5194/acp-42481-2004, 2004.

Wachsmuth, M., Gäggeler, H. W., von Glasow, R., and Ammann, M.: Accommodation coefficient of $\mathrm{HOBr}$ on deliquescent sodium bromide aerosol particles, Atmos. Chem. Phys., 2, 121131, doi:10.5194/acp-2-121-2002, 2002.

Wang, J., Hoffmann, A. A., Park, R. J., Jacob, D. J., and Martin, S. T.: Global distribution of solid and aqueous sulfate aerosols: Effect of the hysteresis of particle phase transitions, J. Geophys. Res., 113, D11206, doi:10.1029/2007jd009367, 2008.

Wang, Y. and Jacob, D.: Anthropogenic forcing on tropospheric ozone and $\mathrm{OH}$ since preindustrial times, J. Geophys. Res., 103, 31123-31135, 1998.

Wang, Y., Jacob, D. J., and Logan, J. A.: Global simulation of tropospheric $\mathrm{O}_{3}-\mathrm{NO}_{\mathrm{x}}$-hydrocarbon chemistry 1 . Model formulation, J. Geophys. Res., 103, 10713-10725, doi:10.1029/98jd00158, 1998.

Warwick, N. J., Pyle, J. A., Carver, G. D., Yang, X., Savage, N. H., O'Connor, F. M., and Cox, R. A.: Global modeling of biogenic bromocarbons, J. Geophys. Res., 111, D24305, doi:10.1029/2006JD007264, 2006.

Wesely, M. L.: Parameterization of surface resistance to gaseous dry deposition in regional-scale numerical models, Atmos. Environ., 23, 1293-1304, 1989.

Wild, O., Zhu, X., and Prather, M. J.: Fast-J: Accurate Simulation of In- and Below-Cloud Photolysis in Tropospheric Chemical Models, J. Atmos. Chem., 37, 245-282, doi:10.1023/a:1006415919030, 2000.

Wu, S., Mickley, L. J., Jacob, D. J., Logan, J. A., Yantosca, R. M., and Rind, D.: Why are there large differences between models in global budgets of tropospheric ozone?, J. Geophys. Res., 112, D05302, doi:10.1029/2006jd007801, 2007.

Yang, X., Cox, R. A., Warwick, N. J., Pyle, J. A., Carver, G. D., O'Connor, F. M., and Savage, N. H.: Tropospheric bromine chemistry and its impacts on ozone: A model study, J. Geophys. Res., 110, D23311, doi:10.1029/2005JD006244, 2005.

Yang, X., Pyle, J. A., and Cox, R. A.: Sea salt aerosol production and bromine release: Role of snow on sea ice, Geophys. Res. Lett., 35, L16815, doi:10.1029/2008GL034536, 2008. 
Yang, X., Pyle, J. A., Cox, R. A., Theys, N., and Van Roozendael, M.: Snow-sourced bromine and its implications for polar tropospheric ozone, Atmos. Chem. Phys., 10, 7763-7773, doi:10.5194/acp-10-7763-2010, 2010.

Yokouchi, Y., Hasebe, F., Fujiwara, M., Takashima, H., Shiotani, M., Nishi, N., Kanaya, Y., Hashimoto, S., Fraser, P., ToomSauntry, D., Mukai, H., and Nojiri, Y.: Correlations and emission ratios among bromoform, dibromochloromethane, and dibromomethane in the atmosphere, J. Geophys. Res., 110, D23309, doi:10.1029/2005JD006303, 2005.
Yvon-Lewis, S. A., Saltzman, E. S., and Montzka, S. A.: Recent trends in atmospheric methyl bromide: analysis of postMontreal Protocol variability, Atmos. Chem. Phys., 9, 59635974, doi:10.5194/acp-9-5963-2009, 2009.

Zhang, L., Jacob, D. J., Liu, X., Logan, J. A., Chance, K., Eldering, A., and Bojkov, B. R.: Intercomparison methods for satellite measurements of atmospheric composition: application to tropospheric ozone from TES and OMI, Atmos. Chem. Phys., 10, 4725-4739, doi:10.5194/acp-10-4725-2010, 2010. 